\title{
Pyrotechnological Connections? Re-investigating the Link between Pottery Firing Technology and the Origins of Metallurgy in the Vinča Culture, Serbia
}

\author{
Silvia Amicone ${ }^{1,2}$, Miljana Radivojević ${ }^{2}$, Patrick Sean Quinn ${ }^{2}$, Christoph Berthold ${ }^{1}$ and \\ Thilo Rehren ${ }^{2,3}$ \\ ${ }^{1}$ Competence Center Archaeometry Baden-Wuerttemberg, Eberhard-Karls-Universität \\ Tübingen, Wilhelmstr. 56, Tübingen 72074, Germany (silvia.amicone@uni-tuebingen.de) \\ ${ }^{2}$ UCL Institute of Archaeology, University College London, 31-34 Gordon Square, London \\ WC1H 0PY, United Kingdom \\ ${ }^{3}$ The Cyprus Institute, 20 Konstantinou Kavafi Street 2121, Aglantzia Nicosia, Cyprus
}

\begin{abstract}
The present paper re-examines the purported relationship between Late Neolithic/Early Chalcolithic pottery firing technology and the world's earliest recorded copper metallurgy at two Serbian Vinča culture sites, Belovode and Pločnik (c. 5350 to 4600 BC). A total of eightyeight well-dated sherds including dark-burnished and graphite-painted pottery that originate across this period have been analysed using a multi-pronged scientific approach in order to reconstruct the raw materials and firing conditions that were necessary for the production of these decorative styles. This is then compared to the pyrotechnological requirements and chronology of copper smelting in order to shed new light on the assumed, yet rarely investigated, hypothesis that advances in pottery firing technology in the late $6^{\text {th }}$ and early $5^{\text {th }}$ millennia BC Balkans were an important precursor for the emergence of metallurgy in this region at around $5000 \mathrm{BC}$. The results of this study and the recent literature indicate that the ability to exert sufficiently close control over the redox atmosphere in a two-step firing process necessary to produce graphite-painted pottery could indeed link these two crafts. However, graphite-painted pottery and metallurgy emerge at around the same time, both benefitting from the pre-existing experience with dark-burnished pottery and an increasing focus on aesthetics and exotic minerals. Thus, they appear as related technologies, but not as one being the precursor to the other.
\end{abstract}

Keywords:

Pyrotechnology;

Late Neolithic;

Vinča culture;

Ceramic technology;

Dark-burnished pottery;

Graphite decoration;

Early metallurgy 


\section{Introduction}

Pyrotechnology is defined as the "deliberate process utilising the control and manipulation of fire" (McDonnell, 2001, p. 493), or put simply, the use of fire as a tool (Bentsen, 2014). The term is commonly used in connection with high temperature processes including cooking, heating, illumination and particularly the production of synthetic materials such as plaster, ceramics, metals and glass (Roberts and Radivojević, 2015, p. 300). The emergence of metallurgy in particular is seen as an important advance in the history of humankind and has been the focus of historical narratives explaining the evolution of social complexity, amongst others (e.g. Childe, 1944; Craddock, 1995; Renfrew, 1973; Wertime, 1964). Debate has focused on the questions of when and where ancient humans first learned to use fire to extract metal from naturally occurring ore (Gourdin and Kingery, 1975; Jovanović and Ottaway, 1976; Jordan and Zvelebil, 2009; McDonnell, 2001; Roberts et al., 2009; Wu et al., 2012, and literature therein). One of the most influential studies on this topic is by Childe (1944), who asserted that the Near Eastern prehistoric communities were the sole inventors of extractive metallurgy, which then spread to other parts of the globe. This view was challenged by Renfrew (1969), who argued instead for multiple inventions of metallurgy in different independent centres across Eurasia, basing the argument largely on artefact typology and C14 dates.

Recent excavations at the 7000 year old Vinča culture site of Belovode in eastern Serbia (Figure 1) and laboratory analysis of unearthed archaeometallurgical artefacts revealed the earliest evidence for copper smelting in Eurasia (Radivojević, et al., 2010; Radivojević, 2013). At Pločnik, a Vinča culture settlement in the south of the country, the recovery of a wellcontextualised tin bronze foil dated to c. $4650 \mathrm{BC}$ has also suggested the presence of a very early but short-lived tin bronze making tradition in the Balkans, technologically linked to the early copper making by Vinča culture communities (Radivojević, et al. 2013). Both discoveries reinforce the theory of multiple independent centres of metallurgy invention in Eurasia, with Iran and possibly the Iberian Peninsula as other likely contemporary metallurgy heartlands alongside the Balkans. Radivojević and Rehren (2016) have suggested that the evolutionary trajectory of copper metallurgy in this part of the world is connected to the knowledge of material properties of black and green manganese-rich copper minerals, which feature as raw materials for both copper and tin bronze making. Such knowledge emerged locally and was subsequently transmitted across the Balkans over the course of c. 2,000 years, starting in the late seventh millennium and continuing into the mid to late fifth millennium BC (Radivojević and Rehren, 2016, p. 228).

Advances in pottery firing technology, which predates metallurgy in many parts of the world, have been proposed as precursors to the emergence of metal extraction (Wertime, 1964 and literature therein). According to this theory, metallurgists gained transferrable skills from potters, including the ability to reduce metal oxides (Wertime, 1964, pp. 1264-1266). This appears to be supported by archaeological evidence from the Balkans, where together with other forms of decoration (e.g. cinnabar, calcite, black-topped) dark-burnished and graphitepainted pottery (Figure 2) are typical productions. The high firing temperatures of about 1000 ${ }^{\circ} \mathrm{C}$ or above and predominantly reducing atmosphere that were assumed to be necessary for the production of dark-burnished and graphite-painted decoration were taken to indicate that potters of the Late Neolithic Balkans already possessed a sophisticated understanding of pyrotechnology and the behaviour of naturally occurring inorganic materials at high temperatures (Gimbutas, 1976, pp. 173-176; Kaiser et al., 1986; Renfrew, 1969) by the time that metallurgy emerged, arguing that this knowledge and skill must have featured as a crucial prerequisite for the development of copper smelting technology. 


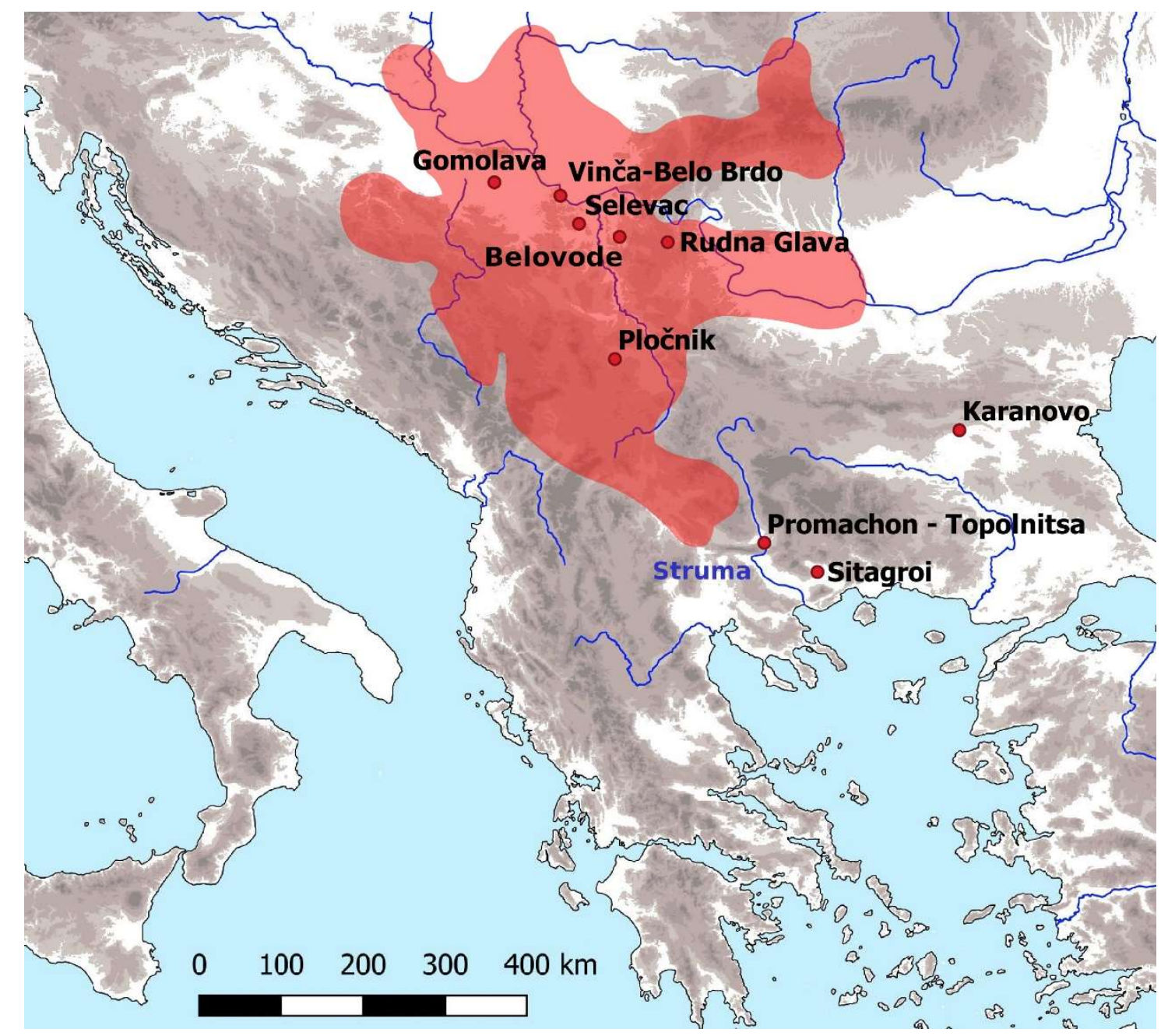

Figure 1. Distribution of the Vinča culture throughout all its periods (shaded) and location of sites mentioned in this study.

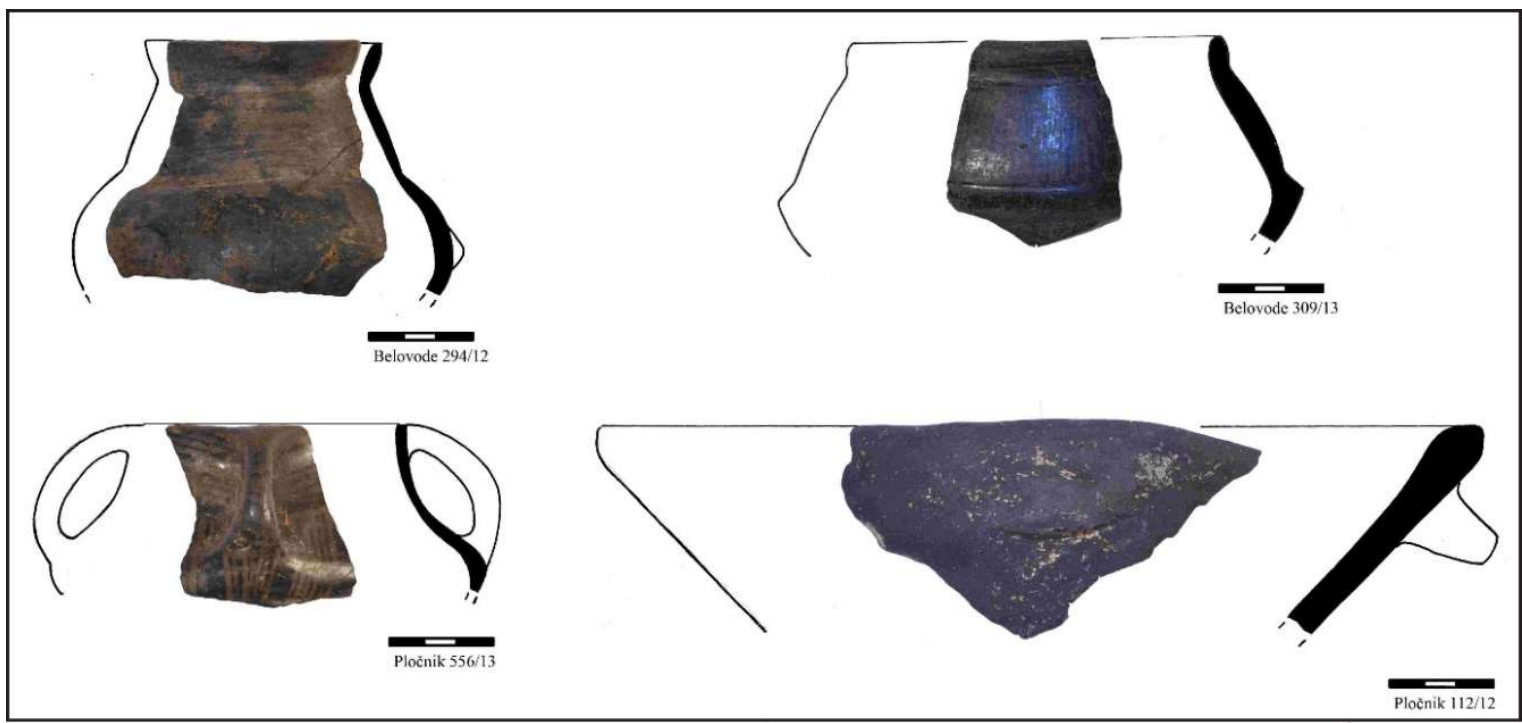

Figure 2. Dark-burnished and graphite-painted pottery sherds from the Vinča culture sites of Belovode and Pločnik (copyright 'Rise of Metallurgy in Eurasia' project at the UCL Institute of Archaeology). 
Whilst this is an attractive and convenient interpretation, it has never been rigorously tested. In particular, an in-depth understanding of the technology involved in the production of darkburnished and graphite-painted pottery in the Vinča Culture is lacking, especially in the context of most recently reported detailed technological studies on the emergence and evolution of metallurgy in this culture (e.g. Radivojević et al., 2010 and literature therein). The present paper addresses this gap in our knowledge by studying in detail a total of eighty-eight welldated sherds that include a relevant selection of dark-burnished and graphite-painted sherds from Belovode and Pločnik (Table 1). Using X-ray powder diffraction (XRPD), scanning electron microscopy (SEM), thin section petrography and traditional macroscopic observations, the raw materials, pyrotechnological conditions and procedures required to produce the ceramics' distinctive decoration have been reconstructed. This has then been compared to the contemporary knowledge of copper production technology at the two studied sites and the Vinča culture in general in order to shed more light on the relationship between pottery making and the emergence of metallurgy, as well as the likelihood that the former was a key precursor to the latter in this part of the world. The study represents a significant contribution to the study of the late Neolithic and early Chalcolithic in the Balkans at a time of remarkable craftsmanship and pyrotechnological advancements by the communities in this region.

\subsection{Archaeological Background}

The Vinča culture is a Neolithic/Chalcolithic phenomenon that covered a vast area comprising parts of the northern and central Balkans, including Macedonia, Serbia, northeast Bosnia, the Vojvodina, southern Transdanubia, the Banat, Oltenia, west Transylvania, and the lower Tisza valley (Figure 1). This cultural phenomenon has been the subject of intense research, including key studies by Chapman $(1977 ; 1981)$, Garašanin (1951; 1979), Marić et al. (2016), Radivojević (2012), Renfrew (1970), Schier (1996), Tasić et al. (2015) and Jovanović (1971). According to published absolute dates, the estimated duration of the Vinča culture ranges from c. 5350 to c. 4600 BC (Breunig, 1987; Ehrich and Bankoff, 1992; Schier, 2000; Whittle et al., 2016) and has been divided into different phases according to the observable stratigraphic sequences and typological developments within the ceramic material culture, with the most widely used divisions based on Garašanin (1951; 1979; 1993) and Milojčić (1949) (supplementary materials).

In this study we focus on the Gradac Phase, which starts at the beginning of the fifth millennium BC (Garašanin, 1994/95; Jovanović, 1993/1994; 2006; Schier, 1996; Whittle et al., 2016) and lasts for around a century in the northern part of the Vinča culture phenomenon (defined as Gradac I-II) or until its end in settlements of the Morava valley and its tributaries in central and south Serbia, termed as Gradac I, II and III (the end varies between c. 4600 and c. 4400 BC, see Radivojević and Grujić, 2018; Radivojević et al., forthcoming). The Gradac Phase has been broadly correlated with the expansion of metallurgy and mining activities in the Vinča culture, particulary at the site of Rudna Glava (Jovanović, 1980; 1993/1994), as well as Belovode and Pločnik (Radivojević and Kuzmanović-Cvetković, 2014).

According to Jovanovic (1993/1994) developments corresponding to the appearance of the Gradac phase clearly denote significant social changes at the time that he linked with the beginning of the Chalcolithic period in the Vinča culture and the entire Balkans. Garašanin (1994/95) also noted that this phase in the broader cultural and geographic context of this region belongs to a clearly distinguished and important period. Therefore, the influence which the appearance of metal had played within the Vinča culture is an important matter of debate, as 
much as its origin. To address themes such as invention, innovation and cultural change, a closer look into the material culture with a technological approach that includes archaeometric analysis seems to be particularly important. The study of the sites of Belovode and Pločnik offers the opportunity to approach these themes by investigating the archaeological records from two sites that gave important evidence for metallurgical activities and accordingly could have played a major role in the invention and adoption of metallurgy in Europe.

The site of Belovode is situated on a plateau located close to the village of Veliko Laole, c. 140 $\mathrm{km}$ southeast of Belgrade (Figure 1). It has yielded the earliest known evidence for copper smelting in the world, dated at around 5000 BC (Radivojević et al., 2010). Pločnik in southern Serbia lies on a fertile floodplain on the left bank of the Toplica River (Figure 1). It yielded the world's earliest known tin-bronze object, dated to approximately $4650 \mathrm{BC}$, alongside more than 40 massive copper implements (e.g. Radivojević et al., 2013; Radivojević and Kuzmanović-Cvetković, 2014). In both sites abundant pottery finds were unearthed, including dark-burnished pottery (Figure 2) coming from different features recognised during the excavations (e.g. dwellings, pits) that belong to building horizons corresponding to different Vinča culture phases (Radivojević et al., forthcoming). In Pločnik graphite-painted sherds emerge in the Gradac phase concurrently with metallurgy, as seen in the case of a copper chisel from Trench 14 that is dated to the context associated with 5040-4860 BC (95\% probability, Radivojević and Kuzmanović-Cvetković, 2014, p. 18).

\subsection{Dark-burnished and Graphite-painted Pottery}

Dark-burnished pottery, also known as black-burnished ware, is a pottery tradition with a widespread distribution during the Late Neolithic across the Balkans (Bonga, 2013, pp. 133178; Chapman, 2006; 2007, p. 296; Holmberg, 1964). According to Garašanin (1954), this pottery type may have originated in Anatolia due to the finds of aesthetically similar pottery, however their technological link to the Balkan examples has never been thoroughly investigated.

Nevertheless, other scholars argue that it could have evolved independently in the Balkans (Chapman, 2006; Childe, 1936/1937, p. 29) based on a few convincing arguments. Darkburnished pottery was one of the main features of Vinča material culture and is found from its earliest development (c. 5350 BC). Also, its colour and brightness well match the Neolithic Balkan visual identity based on striking and dark colours (Chapman 2006; 2007). Besides pottery, other examples for this aesthetical preference include black and green ores used for copper smelting, and obsidian (Radivojević and Rehren, 2016).

The distinctive black or dark grey decoration of the Balkan dark-burnished pottery could have been produced in several different ways including iron reduction, the application of manganese, the deposition of carbon as soot, or painting with graphite pigment. The iron reduction technique fires iron-rich clay above $500^{\circ} \mathrm{C}$ under reducing conditions (Cuomo di Caprio, 2007, p. 121; Jones, 1986, p. 762; Maritan, 2004; Noll, 1991, p. 121). A reducing atmosphere is achieved during firing when little or no 'free oxygen' is available due to restricted air supply or the addition of excess fuel. In this situation, the iron in the clay is reduced to 'ferrous' minerals such as magnetite $\left(\mathrm{Fe}_{3} \mathrm{O}_{4}\right)$, and carbonised amorphous organic matter in the clay is not burnt off, giving the pottery a grey or black colour. Manganese black decoration is formed by the presence of manganese-rich mineral phases such as pyrolusite which are applied to pottery as a pigment or within a clay-rich slip, then fired in oxidising conditions (Jones, 1986, p. 762; Noll, 1991, p. 140; Spataro, 2019). 
Carbon black decoration is typically produced by adding organic material and firing under reducing conditions, resulting in the formation of a layer of charcoal or soot (Jones, 1986, pp. 763-764; Letsch and Noll, 1978; 1983; Noll, 1991, p. 175). A typical method involves 'smudging' (Jones, 1986, pp. 763-764), that is the deposition of carbon on the surface of a vessel and within open pores during the firing process, for example by smothering the pots with fine-textured fuel at the end of the firing. The coating is composed of a very fine crystalline or amorphous carbon (Jones, 1986, p. 763) producing a shiny 'Glanzkohlenstoff' (lustrous carbon) finish (Letsch and Noll, 1978; 1983). Significant technological skill is required to produce carbon black as timing is crucial and it is essential to maintain reducing conditions in order for the coating not to be burnt off. Letsch and Noll (1978) argued that the black finish on Neolithic and Bronze Age pottery from the Balkans, Anatolia, the Near East and Egypt is due to the deposition of carbon primarily from the smudging, but also from the organic matter contained within the clay body.

Painting pottery with graphite pigment is another method of achieving a highly reflective black surface finish (Jones, 1986, p. 768). Vessels with geometric patterns painted in graphite are found across the fifth millennium BC Balkans (e.g. Gaul, 1948, pp. 98-99; Leshtakov, 2005; Martinon, 2017; Todorova, 1986, p. 107). The earliest documented use of graphite decoration is considered to come from Promachon-Topolnica (Fig. 1) in the Struma valley and is dated to the beginning of the fifth millennium (Vajsov, 2007). Within the Vinča culture it appears for the first time during the Gradac phase (Peric 2006, p. 238). Graphite is a crystalline form of carbon that occurs naturally in highly metamorphic rocks such as marble, schist and especially gneiss. It was ground to a fine powder, mixed with water and perhaps clay, then applied, often onto a burnished surface. The reduction during the firing should be well controlled to preserve the graphite layer (Kreiter et al., 2014).

It has been suggested that the use of graphite decoration on pottery was closely related to the emergence of early metal production. Its light-reflective qualities produce a metallic sheen that may have been aesthetically appealing to prehistoric communities (Todorova, 1981). The acquisition of graphite would have required the participation in specialist trade networks comparable to those required for copper exploitation (e.g. Leshtakov, 2005; Radivojević and Grujić, 2018). Another link that has been proposed, as will be discussed below, is that the high temperatures necessary for copper metallurgy (around and exceeding c. $1100{ }^{\circ} \mathrm{C}$ ) could also have been required to produce graphite-painted pottery (Renfrew, 1969).

Noteworthy, the nature of the relationship between the emergence during the Gradac phase of the Vinča Culture of graphite-painted pottery and extractive metallurgy has never been properly investigated.

\subsection{Previous Analytical Studies}

The earliest investigation of the pyrotechnological link between pottery and metallurgy in the Balkans was carried out by Frierman (1969), who analysed a late fifth millennium BC darkburnished sherd decorated with graphite from the site of Karanovo in Bulgaria (Karanovo VI) by determining its fusion point via thermal analysis. He estimated that the sample had been fired to a temperature around $1050{ }^{\circ} \mathrm{C}$ in a strongly reducing atmosphere. The latter was beneficial for graphite application, since under oxidising conditions graphite burns off above c. $725^{\circ} \mathrm{C}$. Frierman (1969) therefore suggested that firing took place in a kiln, given the high temperature and prolonged period of reduction required to produce this type of pottery. This finding was taken forward by Renfrew $(1969$, p. 38) who suggested that "refractory technology in the south-east European Chalcolithic had evolved sufficiently in the firing of pottery to 
provide the conditions required for smelting and casting of copper". However, a few years later Kingery and Frierman (1974) re-fired the same sherd at 700, 800, 900 and $1000{ }^{\circ} \mathrm{C}$ in reducing conditions and concluded that it had in fact been subjected to a maximum temperature of $<800$ ${ }^{\circ} \mathrm{C}$, and possibly as low as $700{ }^{\circ} \mathrm{C}$.

Kaiser et al. (1986) studied the firing temperature of dark-burnished pottery and other pottery types from the Vinča culture sites of Selevac and Gomolava in Serbia via thermal expansion (also Kaiser and Lucius, 1989) and SEM to document the vitrification microstructure. This indicated that the ceramics they studied were variously fired between 850 and $1000{ }^{\circ} \mathrm{C}$ under oxygen-poor conditions. Despite this variability, the authors concluded that potters of the western Balkans were routinely capable of achieving temperatures of $1000{ }^{\circ} \mathrm{C}$ under reducing atmospheres, and that this pointed to a sophisticated knowledge of the firing process, including managing the required resources of labour, fuel and time. Since the pottery came from different contexts at these two relatively distant sites (c. $100 \mathrm{~km})$, it may be inferred that this knowledge was widely shared between Vinča culture communities at the time and could have been transferred to craftspeople who specialised in other pyrotechnologies, such as the smelting of copper metal.

Other studies on the firing of dark-burnished and graphite-painted pottery from the Balkans and Greece include those by Maniatis and Tite (1981), Goleanu et al. (2005), Gardner (1978; 1979; 2003), Yiouni (1995; 2000; 2001), Perišić et al. (2016) and Spataro (2014; 2017; 2018). Among these, Perišić et al. and Spataro focused especially on Vinča pottery. Perišić and coworkers (2016) analysed ten samples from Pločnik, but only a few were dark-burnished, and their typology and chronology were not contextually secure. The research of Spataro (2018) includes the materials from the eponymous site of Vinča Belo Brdo, originating from contexts excavated between 1930 and 1936 by Miloje Vasić, which have no direct association with metal artefacts from this site. All these studies applied a wide range of techniques including thin section petrography, SEM, re-firing tests, FTIR, XRPD and thermo-analytical studies. These investigations revealed that firing temperatures were highly variable, and unlike the findings of Frierman (1969) and Kaiser et al. (1986), did not appear to have exceeded $900{ }^{\circ} \mathrm{C}$. Gardner (1978; 2003, p. 289) observed that graphite-painted vessels from Phases III from the site of Sitagroi in Greece (Figure 1) have a red core, suggesting that the firing process involved two steps. This may have included an initial firing step under oxidising conditions below 700 ${ }^{\circ} \mathrm{C}$, followed by a second smoky reduction phase.

Thus, considerable uncertainty surrounds the topic of Late Neolithic/Chalcolithic ceramic pyrotechnology in the Balkans, particularly the conditions required to achieve dark-burnished and graphite-painted decorations and their role in the inception of early metallurgy. It appears that too much emphasis has been placed on firing temperature and not enough attention has been given to other pyrotechnological parameters such as the redox conditions and length of firing. The former is of crucial importance to the process of smelting copper (Gardner, 1979, pp. 20-21; Rehren, 1997), as a reducing environment is necessary for the formation of metallic copper, the chemical change starting at temperatures as low as $700{ }^{\circ} \mathrm{C}$, whilst a more oxidising environment and a rise in temperatures up to the melting point of pure copper at $1083{ }^{\circ} \mathrm{C}$ are required to initiate the physical change from solid to liquid metal (Pollard et al., 1991; Radivojević et al., 2010). 


\section{Materials and Methods}

Eighty-eight Vinča culture pottery sherds were selected from the sites of Belovode and Pločnik in order to investigate the pyrotechnology necessary to produce dark-burnished pottery and graphite decoration (Table 1). Twenty-nine of these were chosen from the assemblage of Trench 18 in Belovode, while at Pločnik fifty-nine samples were taken from Trenches 20, 21 and 24. The selected samples come from different features recognised during the excavations (e.g. dwellings, pits), represent various types of pottery found within the excavated assemblages, and come from different building horizons (1-5) corresponding to different Vinča culture phases of the settlements (Radivojević et al. forthcoming). Horizon 1 is the youngest, while horizon 5 belongs to the earliest layers of occupation in both sites. Also, both sites share the similarity of the youngest (horizon 1) showing a possible evidence for abandonment and destruction. In Belovode horizon 1 belongs to Vinca C-D, horizons 2 and 3 to Gradac and Vinca B1-B2, horizon 4 and 5 to Vinca A and Starčevo. While dark-burnished pottery spread throughout, the graphite pained pottery is not known from this site. In Pločnik, horizon 1 is related to Gradac II and III, horizons 2 and 3 to Gradac I, horizon 4 to B2 and horizon 5 to Vinca A2-B1. All graphite-painted pottery come from horizons 2 and 3, which is the beginning of the Gradac phase on this site, concurrent with the appearance of the earliest metal artefacts as well.

The raw materials and technology involved in the production of the eighty-eight sherds and their decorative finishes was investigated in detail using a combination of macroscopic and instrumental analyses, including thin section petrography, XRPD and SEM. The colour variability within individual sherds was recorded using a Munsell colour chart (Table 2) in order to shed light on their atmosphere of firing (Mentesana, 2017; Rice, 2015, pp. 276-290). The birefringence or 'optical activity' of the sherds in section under the polarising light microscope was used to determine the degree to which they had undergone vitrification during firing (Quinn, 2013, p. 190; Whitbread, 1995, p. 382).

The mineralogical composition of the ceramic body was determined via XRPD and used to reconstruct their original firing temperature ('archaeothermometry', Rice, 2015, pp. 99-116; Quinn and Benzonelli, 2018). This method makes use of the presence/absence of mineral phases that form or disappear at specific temperatures and atmospheric conditions, as determined experimentally and reported in 'bar diagrams' (Maggetti, 1982, p. 128; Maritan, 2004, p. 304; Maritan et al., 2007, p. 533; Nodari et al., 2007, p. 4668) (Figure 3).

For XRPD analysis, the surface layer of each sherd was removed with a tungsten carbide drill and discarded, and c. $1 \mathrm{~g}$ from the body were ground to a fine powder and dried for 12 hours at $110{ }^{\circ} \mathrm{C}$. Initial characterisation of all samples was performed using a Rigaku MiniFlex 600 $\mathrm{X}$-ray diffractometer equipped with a $\mathrm{Cu}$-X-ray tube running at $40 \mathrm{kV} / 30 \mathrm{~mA}$ and a graphite primary monochromator. This was used to select specific samples (Figure 5) for more detailed analysis using a Bruker D8Advance powder diffractometer with a $\mathrm{Cu}$-X-ray tube running at 40 $\mathrm{kV} / 20 \mathrm{~mA}$, with a Goebel mirror optic, a $0.2 \mathrm{~mm}$ divergence slit, a fixed knife edge to suppress air scatter, sample rotation and a VANTEC-1 detector. Mineral identification was performed by matching the spectra against the 2006 International Centre for Diffraction Data-Joint Committee of Power Diffraction Standards (ICDD-JCPDS) database. 


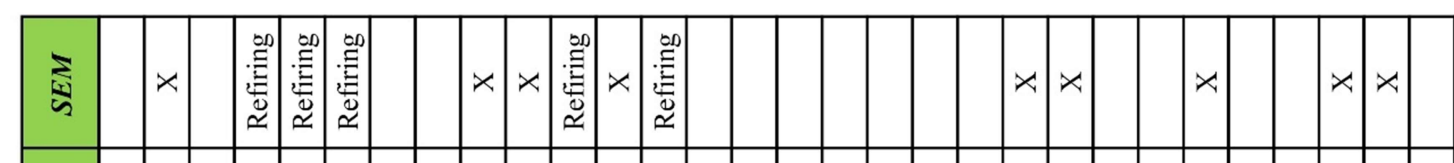

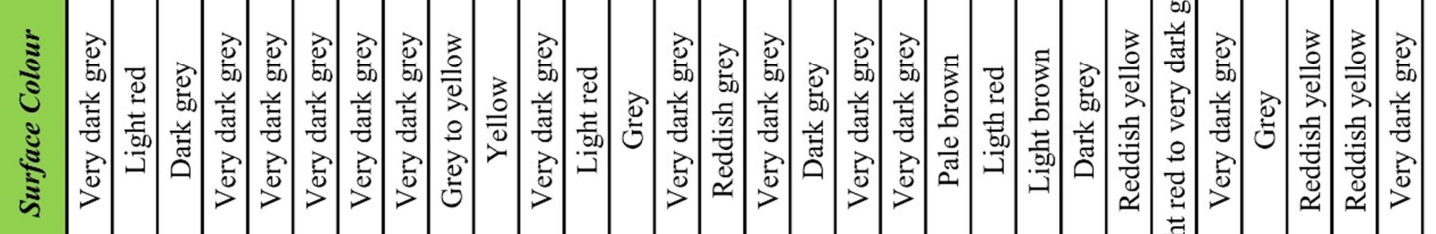

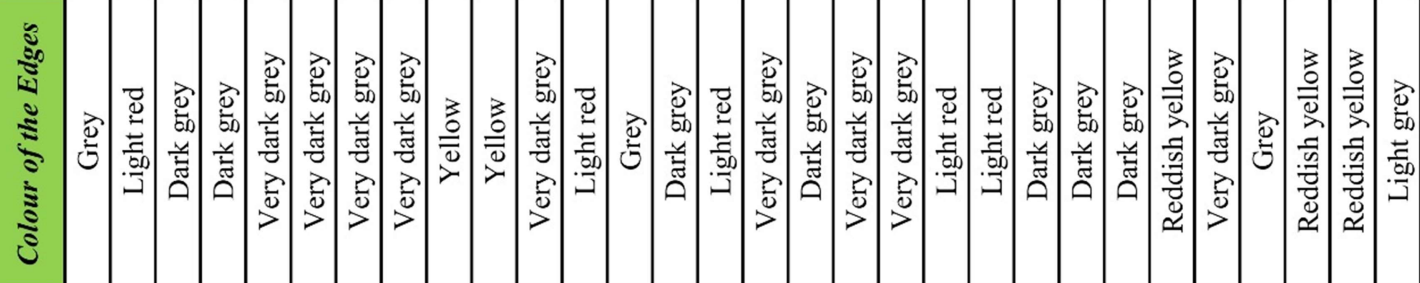

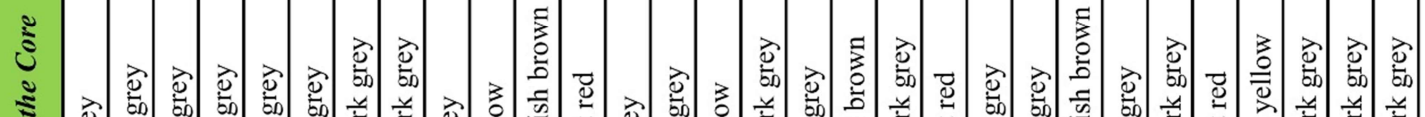
ऽ

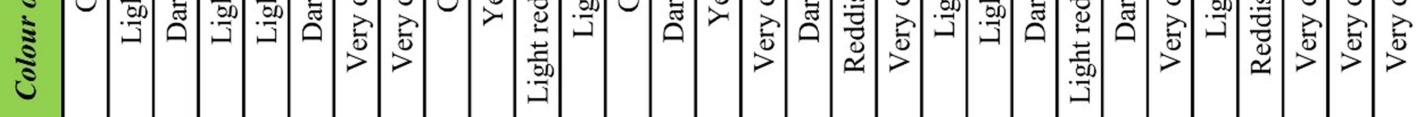

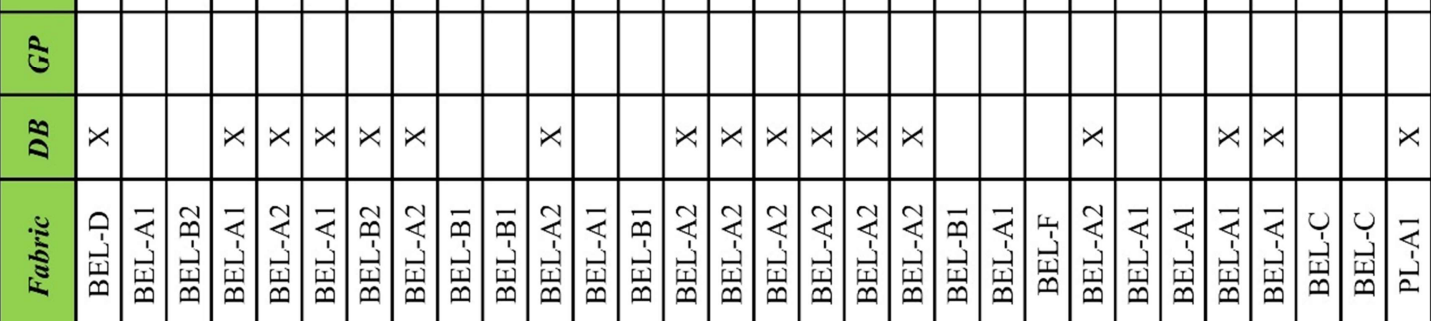

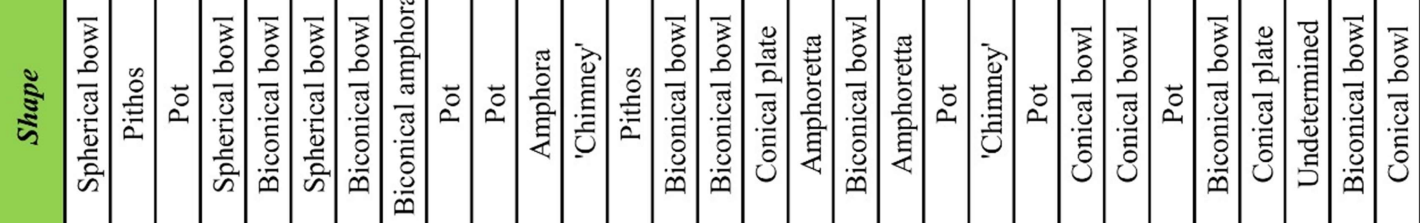

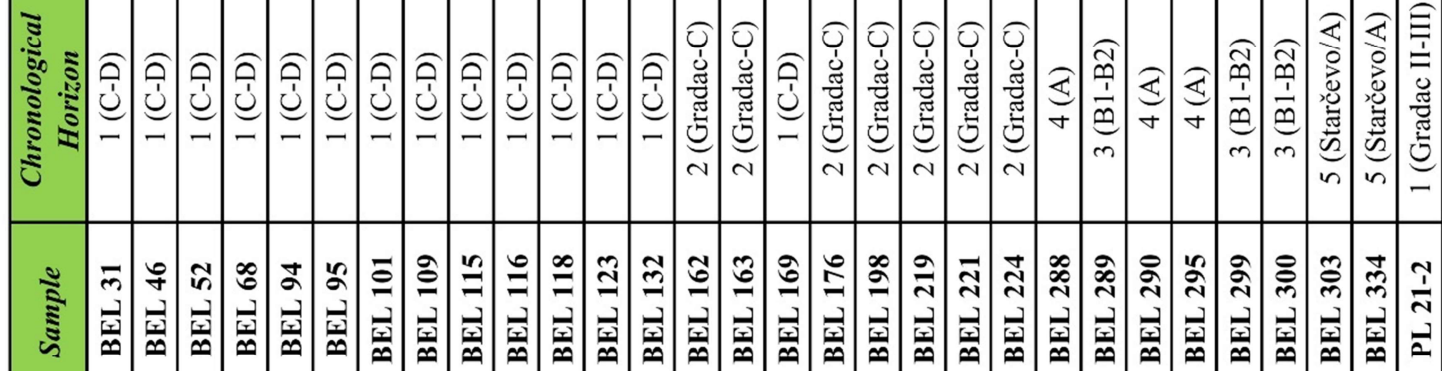




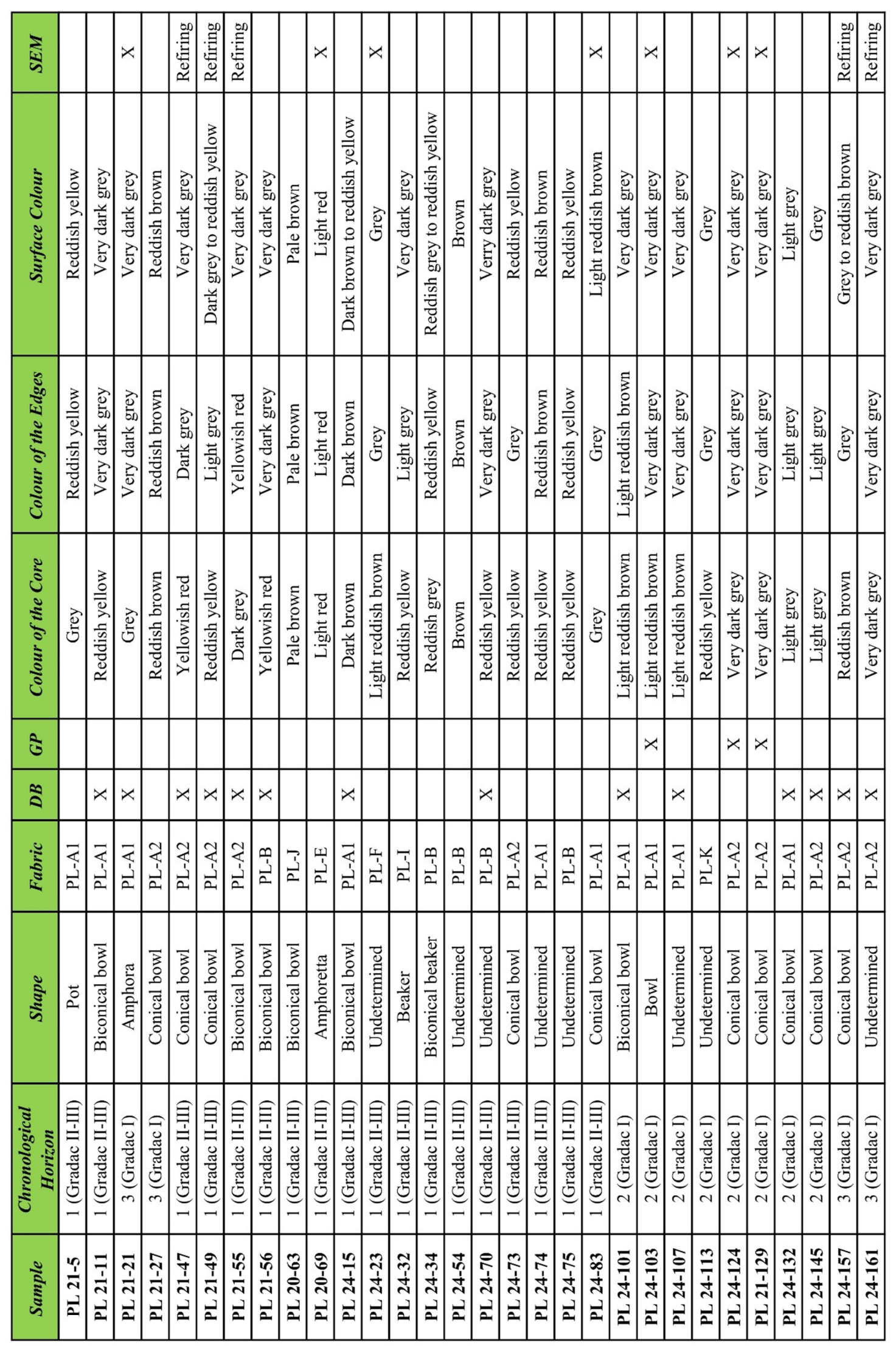




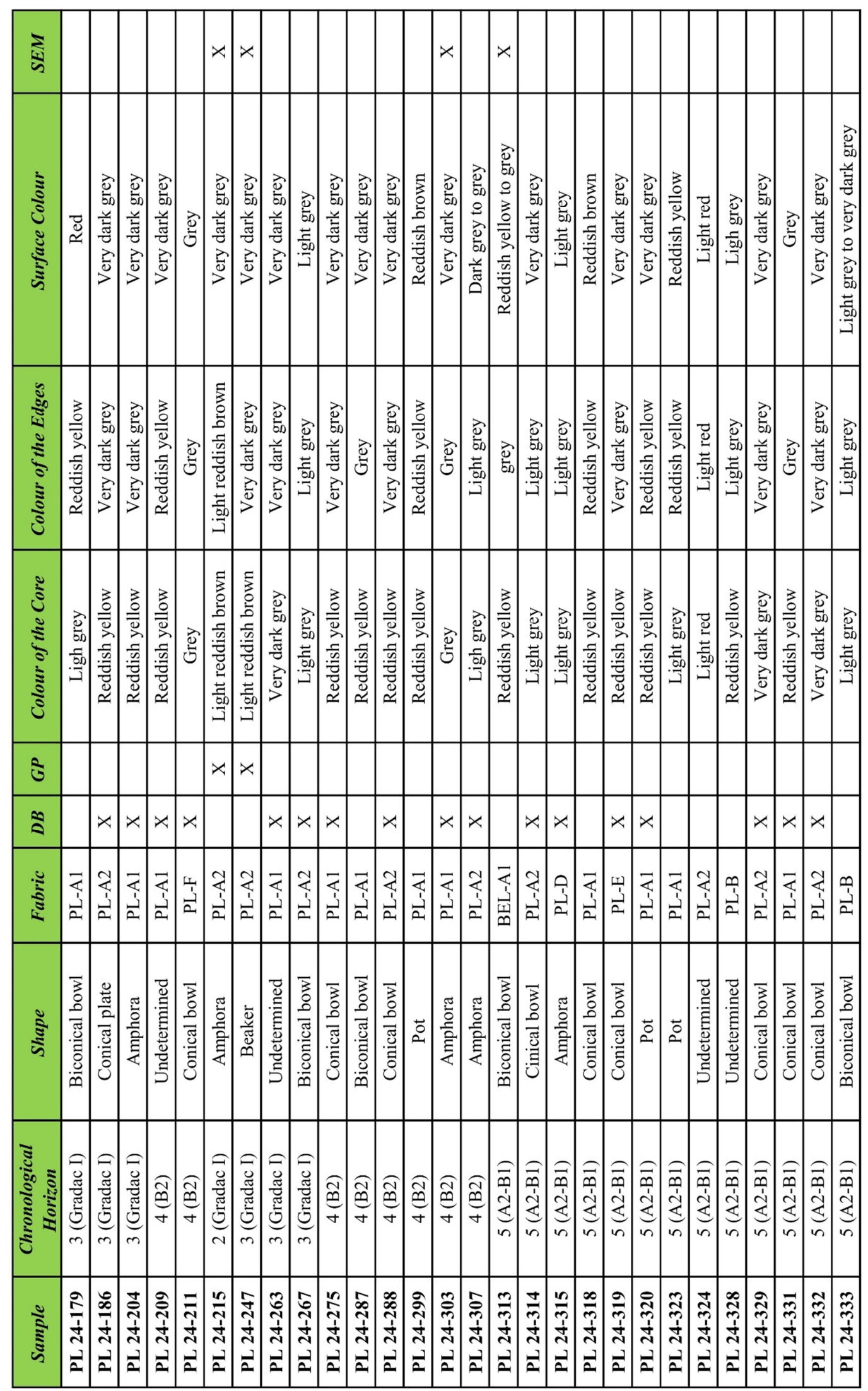

Table 1. Details of eighty-eight pottery samples from the Vinča culture sites of Belovode and Pločnik analysed in the present study with indication of building horizons and corresponding Vinča culture chronological phases ( $\mathrm{DB}=$ dark-burnished; $\mathrm{GP}=$ graphite-painted). 


\begin{tabular}{|l|l|}
\hline Colour & Munsell Code \\
\hline Light red & $(2.5 \mathrm{YR} 6 / 8-10 \mathrm{R} 7 / 8)$ \\
\hline Dark grey & $(5 \mathrm{YR} 3 / 1)$ \\
\hline Reddish brown & $(5 \mathrm{YR} 1 / 3)$ \\
\hline Yellowish red & $(5 \mathrm{YR} 4 / 6-5 / 4)$ \\
\hline Reddish grey & $(5 \mathrm{YR} 5 / 2)$ \\
\hline Grey & $(5 \mathrm{YR} 6 / 1)$ \\
\hline Light reddish brown & $(5 \mathrm{YR} 6 / 3-6 / 4)$ \\
\hline Light grey & $(5 \mathrm{YR} 7 / 1)$ \\
\hline Reddish yellow & $(5 \mathrm{YR} 7 / 6)$ \\
\hline Dark brown & $(7.5 \mathrm{YR} 3 / 1)$ \\
\hline Brown & $(7.5 \mathrm{YR} 5 / 3)$ \\
\hline Very dark grey & $(10 \mathrm{YR} 3 / 1)$ \\
\hline Pale brown & $(10 \mathrm{YR} 6 / 3)$ \\
\hline Yellow & $(10 \mathrm{YR} 7 / 6)$ \\
\hline Red & $(10 \mathrm{R} 4 / 8)$ \\
\hline
\end{tabular}

Table 2. Munsell codes corresponding to the colours provided in Table 1.

\begin{tabular}{|l|l|}
\hline \multicolumn{2}{|c|}{ Pločnick } \\
\hline \multicolumn{1}{|c|}{ Fabric } & \multicolumn{1}{c|}{ Description } \\
\hline PL-A1 & Sedimentary rock fabric, coarse \\
\hline PL-A2 & Sedimentary rock fabric, fine \\
\hline PL-B & Micaschist rock fabric \\
\hline PL-D & Phyllite fabric \\
\hline PL-E & Epidote fabric \\
\hline PL-F & Volcanic rock fabric \\
\hline PL-I & Serpentinite fabric \\
\hline PL-J & Amphibole fabric \\
\hline PL-K & Amphibolite fabric \\
\hline
\end{tabular}

\begin{tabular}{|c|l|}
\hline \multicolumn{2}{|c|}{ Belovode } \\
\hline Fabric & \multicolumn{1}{|c|}{ Description } \\
\hline BEL-A1 & Metasedimentary rock fabric, coarse \\
\hline BEL-A2 & Metasedimentary rock fabric, fine \\
\hline BEL-B1 & Fossiliferous fabric coarse \\
\hline BEL-B2 & Fossiliferous fabric fine \\
\hline BEL-C & Chaff tempered fabric \\
\hline BEL-D & Very fine fabric \\
\hline BEL-F & Metamorphic fabric with weathered plagioclase \\
\hline
\end{tabular}

Table 3. Petrographic fabrics corresponding to the abbreviations used in Table 1. 


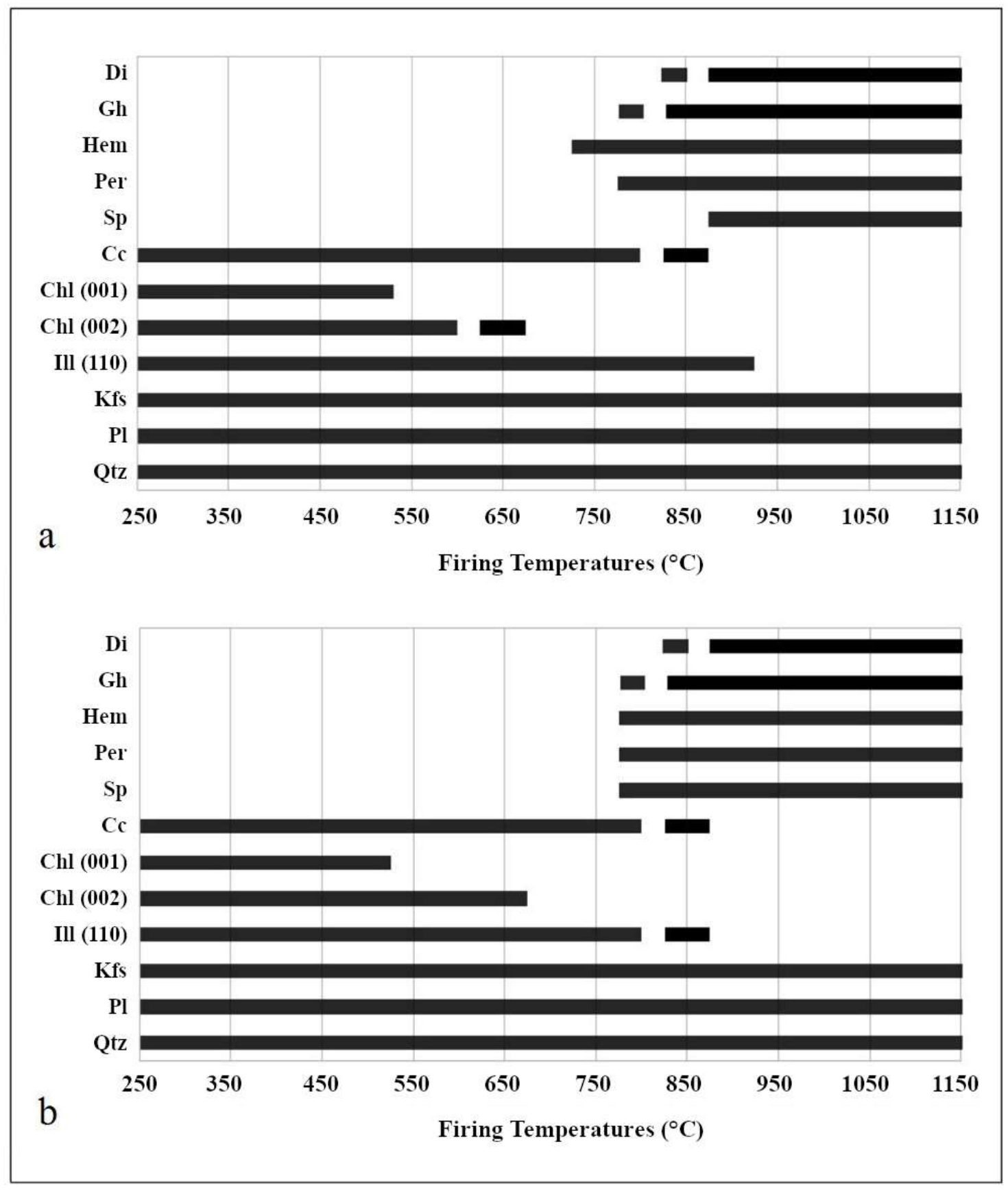

Figure 3. Bar diagrams documenting the mineralogical changes that take place during the firing of earthenware ceramics in oxidising (a) and reducing (b) atmosphere. Modified after Maritan 2004, p. 304, figure 7). Mineral abbreviations: $\mathrm{Di}=$ diopside; $\mathrm{Gh}=$ gehlenite; Hem = hematite; $\mathrm{Mag}=$ magnetite; $\mathrm{Per}=$ periclase $\mathrm{Sp}=$ spinel; $\mathrm{Cc}=$ calcite $; \mathrm{Chl}=$ chlorite; $\mathrm{Ill}=$ illite; $\mathrm{Kfs}=$ potassium feldspar; $\mathrm{Pl}=$ plagioclase; $\mathrm{Qtz}=$ quartz.

Selected samples from Belovode $(n=14)$ and Pločnik $(n=16)$ (Table 1) were also examined in fresh fracture under the SEM. The vitrification microstructure of the clay matrix was compared to published studies including Faber et al. (2009), Maniatis and Tite $(1975 ; 1981)$ and Tite and Maniatis $(1975 \mathrm{a} ; 1975 \mathrm{~b})$ to provide an alternative assessment of firing temperature. Subsamples of five dark-burnished pottery sherds from each site (Table 1) were re-fired at $700,750,800,850,900,950,1000,1050$ and $1100{ }^{\circ} \mathrm{C}$, respectively, for one hour under reducing conditions, then studied in the SEM and their vitrification compared to the original 
specimens (Wolf, 2002). The samples were all gold coated and the analysis was carried out on a HITACHI S-3400N SEM using an accelerating voltage of $5 \mathrm{kV}$ and an operating current of $110 \mu \mathrm{A}$ with a variable working distance.

Non-destructive and locally resolved characterisation of the decoration of five 'graphitepainted' sherds from Pločnik was performed via X-ray microdiffraction $\left(\mu-X_{R}{ }^{2}\right)$ using a Bruker D8 Discover-GADDS microdiffractometer with a Co-X-ray tube running at $30 \mathrm{kV} / 30$ $\mathrm{mA}$, a graphite primary monochromator and a $500 \mu \mathrm{m}$ monocapillary X-ray optics with a 300 $\mu \mathrm{m}$ and a large 2-dimensional VANTEC-500 detector covering app. $40^{\circ}$ in ${ }^{\circ} 2 \Theta$ and ${ }^{\circ} \mathrm{Chi}$. ( $\mathrm{He}$, 2018; Berthold et al., 2015; Berthold and Mentzer, 2017). Micro-Raman spectroscopy was also performed using a Renishaw InVIA Reflex Raman microscope with a $532 \mathrm{~nm}$ laser for excitation and a 50x objective to discriminate between the different carbon modifications (Cuesta et al., 1998).

\section{Results}

The majority of the pottery from Belovode has a pale yellow to reddish yellow surface colour that indicates firing under oxidising conditions (Amicone, 2017, p. 152). Only those vessels with burnished/polished surfaces appear to have been fired under reducing conditions, resulting in a darker light grey to very dark grey/black colour. Few of these display a homogenous very dark grey/black colour across their surface. In contrast, at Pločnik approximately $60 \%$ of the sherds from all five horizons exhibit grey and black shades associated with burnishing/polishing and more rarely with graphite decoration (Amicone, 2017, p. 190). These originate from bowls, pithoi, amphorae, amphorettae and other larger pots. This preference for dark pottery persists into Horizon 1 (Gradac III), although there is only rare evidence for burnishing at this point. Some black-topped sherds occur at both sites, for example in Horizons 4 and 5 (Vinča A2-B2). The colour of most of the examined sherds varies in cross section, indicating variable atmospheric conditions during firing and/or a short firing duration (Figure 4). Fragments from Pločnik decorated with graphite exhibit a relatively homogeneous dark to light grey fabric in cross section (Figure $4 \mathbf{f}$ and $\mathbf{h}$ ).

The petrographic composition of the ceramics from both sites and its comparison with the bedrock geology and raw material field samples indicates that the vast majority of specimens were locally produced with non-calcareous clay pastes (Amicone, 2017, pp. 154-160 and 192198). The degree of optical activity of the clay matrices of the sherds under the microscope in crossed polarisers varies from sample to sample (Table 4). Some specimens especially those originating from layers in horizon 1 of both sites are optically inactive, suggesting firing above $900{ }^{\circ} \mathrm{C}$. The majority of specimens exhibit weak to high optical activity indicating lower firing temperatures.

X-ray powder diffraction revealed a mineralogical assemblage of quartz and feldspar and less frequently amphibole. The majority of the samples also show illite (Table 4; Figure 5), though the identification of this clay mineral is hindered when muscovite is present due to the overlap between the main illite and muscovite peaks. Some samples exhibit a weak diffraction peak corresponding to a d-value of approximately $14 \AA$ (Figure 5 c), which points to either chlorite or probably montmorillonite. 

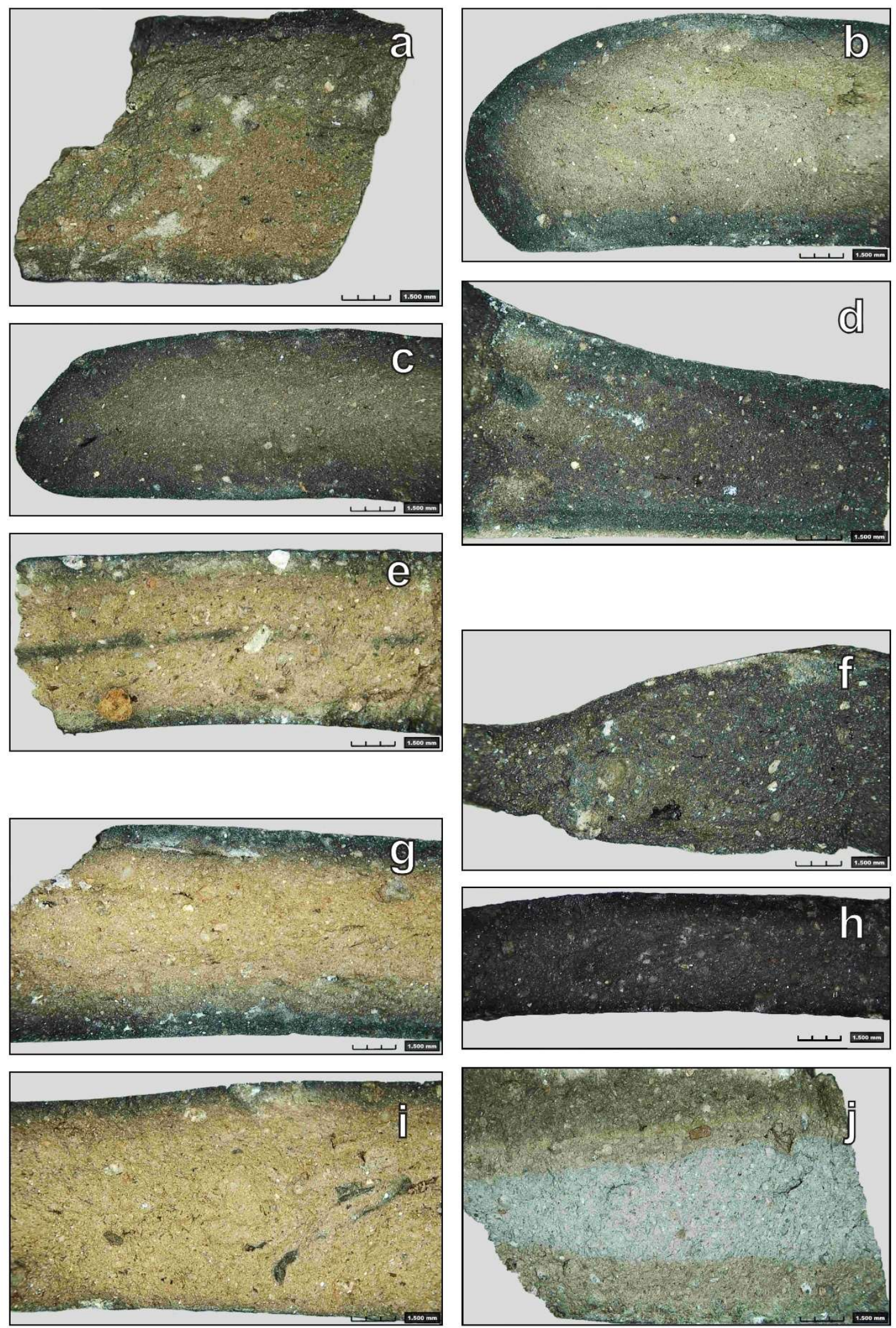

Figure 4. Selected dark-burnished and graphite-painted pottery sherds from the Vinča culture sites of Belovode seen in fresh break, revealing the fired colour of their fabric and the presence of firing horizons: a) BEL 289; b) BEL 94; c) BEL162; d) BEL 219; e) BEL 299; f) PL 24-129 (graphite-painted); g) PL 24-107; h) PL 24-124 (graphite-painted); i) PL 24-288; j) PL 24-145. 


\begin{tabular}{|c|c|c|c|c|c|c|c|c|c|c|c|c|c|c|}
\hline Sample & $\begin{array}{c}\text { Chronological } \\
\text { Horizon }\end{array}$ & $D B$ & $G P$ & $\begin{array}{l}\text { Optical } \\
\text { Activity }\end{array}$ & $Q t z$ & $F s p$ & $C c$ & $A m$ & IIl & $M s c$ & $\mathrm{Hem}$ & $\mathrm{Cri}$ & $S p l$ & Temp \\
\hline BEL 31 & $1(\mathrm{C}-\mathrm{D})$ & $\mathrm{X}$ & & high & $\mathrm{X}$ & $\mathrm{X}$ & & & $\mathrm{X}$ & & & & & $<900{ }^{\circ} \mathrm{C}$ \\
\hline BEL 46 & $1(\mathrm{C}-\mathrm{D})$ & & & absent & $\mathrm{X}$ & $\mathrm{X}$ & & & & & $\mathrm{X}$ & $\mathrm{X}$ & $\mathrm{X}$ & $>1000^{\circ} \mathrm{C}$ \\
\hline BEL 52 & $1(\mathrm{C}-\mathrm{D})$ & & & weak & $\mathrm{X}$ & $\mathrm{X}$ & $\mathrm{X}$ & & $\mathrm{X}$ & & & & & $<900^{\circ} \mathrm{C}$ \\
\hline BEL 68 & $1(\mathrm{C}-\mathrm{D})$ & $\mathrm{X}$ & & moderate & $\mathrm{X}$ & $\mathrm{X}$ & & & $\mathrm{X}$ & & & & & $<900^{\circ} \mathrm{C}$ \\
\hline BEL 94 & 1 (C-D) & $\mathrm{X}$ & & moderate & $\mathrm{X}$ & $\mathrm{X}$ & & & $\mathrm{X}$ & & & & & $<900^{\circ} \mathrm{C}$ \\
\hline BEL 95 & 1 (C-D) & $\mathrm{X}$ & & high & $\mathrm{X}$ & $\mathrm{X}$ & & & $\mathrm{X}$ & & & & & $<900^{\circ} \mathrm{C}$ \\
\hline BEL 101 & $1(\mathrm{C}-\mathrm{D})$ & $\mathrm{X}$ & & high & $X$ & $\mathrm{X}$ & $\mathrm{X}$ & & $\mathrm{X}$ & & & & & $<900^{\circ} \mathrm{C}$ \\
\hline BEL 109 & $1(\mathrm{C}-\mathrm{D})$ & $X$ & & weak & $\mathrm{X}$ & $\mathrm{X}$ & & $\mathrm{X}$ & $X$ & & & & & $<900^{\circ} \mathrm{C}$ \\
\hline BEL 115 & $1(\mathrm{C}-\mathrm{D})$ & & & moderate & $\mathrm{X}$ & $\mathrm{X}$ & $\mathrm{X}$ & & $\mathrm{X}$ & & & & & $<900^{\circ} \mathrm{C}$ \\
\hline BEL 116 & $1(\mathrm{C}-\mathrm{D})$ & & & high & $\mathrm{X}$ & $\mathrm{X}$ & $\mathrm{X}$ & & $\mathrm{X}$ & & & & & $<900^{\circ} \mathrm{C}$ \\
\hline BEL 118 & $1(\mathrm{C}-\mathrm{D})$ & $\mathrm{X}$ & & weak & $\mathrm{X}$ & $\mathrm{X}$ & & & $\mathrm{X}$ & & & & & $<900^{\circ} \mathrm{C}$ \\
\hline BEL 123 & 1 (C-D) & & & absent & $\mathrm{X}$ & $\mathrm{X}$ & & & & & $\mathrm{X}$ & $\mathrm{X}$ & $\mathrm{X}$ & $>1000^{\circ} \mathrm{C}$ \\
\hline BEL 132 & $1(\mathrm{C}-\mathrm{D})$ & & & weak & $X$ & $\mathrm{X}$ & $\mathrm{X}$ & & $\mathrm{X}$ & & & & & $<900^{\circ} \mathrm{C}$ \\
\hline BEL 162 & 2 (Gradac-C) & $\mathrm{X}$ & & moderate & $\mathrm{X}$ & $\mathrm{X}$ & & $\mathrm{X}$ & $\mathrm{X}$ & & & & & $<900^{\circ} \mathrm{C}$ \\
\hline BEL 163 & 2 (Gradac-C) & $\mathrm{X}$ & & high & $\mathrm{X}$ & $\mathrm{X}$ & & & $\mathrm{X}$ & & & & & $<900^{\circ} \mathrm{C}$ \\
\hline BEL 169 & $1(\mathrm{C}-\mathrm{D})$ & $X$ & & weak & $\mathrm{X}$ & $\mathrm{X}$ & & & $\mathrm{X}$ & & & & & $<900^{\circ} \mathrm{C}$ \\
\hline BEL 176 & 2 (Gradac-C) & $\mathrm{X}$ & & weak & $\mathrm{X}$ & $\mathrm{X}$ & & & $\mathrm{X}$ & & & & & $<900^{\circ} \mathrm{C}$ \\
\hline BEL 198 & 2 (Gradac-C) & $X$ & & weak & $X$ & $\mathrm{X}$ & & & $X$ & & & & & $<900^{\circ} \mathrm{C}$ \\
\hline BEL 219 & 2 (Gradac-C) & $\mathrm{X}$ & & moderate & $\mathrm{X}$ & $\mathrm{X}$ & & $\mathrm{X}$ & $\mathrm{X}$ & & & & & $<900^{\circ} \mathrm{C}$ \\
\hline BEL 221 & 2 (Gradac-C) & & & absent & $\mathrm{X}$ & $\mathrm{X}$ & $X$ & & $X$ & & & & & $<900^{\circ} \mathrm{C}$ \\
\hline BEL 224 & 2 (Gradac-C) & & & absent & $\mathrm{X}$ & $\mathrm{X}$ & & & & & $X$ & $\mathrm{X}$ & $X$ & $>1000^{\circ} \mathrm{C}$ \\
\hline BEL 288 & $4(\mathrm{~A})$ & & & absent & $X$ & $\mathrm{X}$ & & & $\mathrm{X}$ & & & & & $<900{ }^{\circ} \mathrm{C}$ \\
\hline BEL 289 & 3 (B1-B2) & $\mathrm{X}$ & & moderate & $\mathrm{X}$ & $\mathrm{X}$ & & & $\mathrm{X}$ & & & & & $<900^{\circ} \mathrm{C}$ \\
\hline BEL 290 & $4(\mathrm{~A})$ & & & absent & $\mathrm{X}$ & $\mathrm{X}$ & & & $\mathrm{X}$ & & & & & $<900^{\circ} \mathrm{C}$ \\
\hline BEL 295 & $4(\mathrm{~A})$ & & & weak & $\mathrm{X}$ & $\mathrm{X}$ & & & $\mathrm{X}$ & & & & & $<900^{\circ} \mathrm{C}$ \\
\hline BEL 299 & 3 (B1-B2) & $\mathrm{X}$ & & moderate & $\mathrm{X}$ & $\mathrm{X}$ & & & $\mathrm{X}$ & & & & & $<900^{\circ} \mathrm{C}$ \\
\hline BEL 300 & 3 (B1-B2) & $\mathrm{X}$ & & high & $\mathrm{X}$ & $\mathrm{X}$ & $\mathrm{X}$ & & $\mathrm{X}$ & & & & & $<900^{\circ} \mathrm{C}$ \\
\hline BEL 303 & 5 (Starčevo/A) & & & weak & $\mathrm{X}$ & $\mathrm{X}$ & & & $X$ & & & & & $<900^{\circ} \mathrm{C}$ \\
\hline BEL 334 & $5($ Starčevo/A) & & & weak & $\mathrm{X}$ & $\mathrm{X}$ & & & $\mathrm{X}$ & & & & & $<900^{\circ} \mathrm{C}$ \\
\hline PL 21-2 & 1 (Gradac II-III) & $\mathrm{X}$ & & moderate & $\mathrm{X}$ & $\mathrm{X}$ & & & $\mathrm{X}$ & & & & & $<900^{\circ} \mathrm{C}$ \\
\hline PL 21-5 & 1 (Gradac II-III) & & & moderate & $\mathrm{X}$ & $\mathrm{X}$ & & & $\mathrm{X}$ & & & & & $<900^{\circ} \mathrm{C}$ \\
\hline PL 21-11 & 1 (Gradac II-III) & $\mathrm{X}$ & & weak & $\mathrm{X}$ & $\mathrm{X}$ & & & $X$ & & & & & $<900^{\circ} \mathrm{C}$ \\
\hline PL 21-21 & 3 (Gradac I) & $\mathrm{X}$ & & weak & $\mathrm{X}$ & $\mathrm{X}$ & & & $\mathrm{X}$ & & & & & $<900^{\circ} \mathrm{C}$ \\
\hline PL 21-27 & 3 (Gradac I) & & & moderate & $\mathrm{X}$ & $\mathrm{X}$ & & & $\mathrm{X}$ & & & & & $<900^{\circ} \mathrm{C}$ \\
\hline PL 21-47 & 1 (Gradac II-III) & $\mathrm{X}$ & & moderate & $\mathrm{X}$ & $\mathrm{X}$ & & & $\mathrm{X}$ & & & & & $<900^{\circ} \mathrm{C}$ \\
\hline PL 21-49 & 1 (Gradac II-III) & $\mathrm{X}$ & & absent & $\mathrm{X}$ & $\mathrm{X}$ & & & $\mathrm{X}$ & & & & & $<900^{\circ} \mathrm{C}$ \\
\hline PL 21-55 & 1 (Gradac II-III) & $\mathrm{X}$ & & weak & $\mathrm{X}$ & $\mathrm{X}$ & & & $\mathrm{X}$ & & & & & $<900^{\circ} \mathrm{C}$ \\
\hline PL 21-56 & 1 (Gradac II-III) & $\mathrm{X}$ & & weak & $\mathrm{X}$ & $\mathrm{X}$ & & & $\mathrm{X}$ & & & & & $<900^{\circ} \mathrm{C}$ \\
\hline PL 20-63 & 1 (Gradac II-III) & & & weak & $\mathrm{X}$ & $\mathrm{X}$ & & $\mathrm{X}$ & $\mathrm{X}$ & $\mathrm{X}$ & $\mathrm{X}$ & $\mathrm{X}$ ? & & $>1000^{\circ} \mathrm{C}$ \\
\hline PL 20-69 & 1 (Gradac II-III) & & & absent & $X$ & $\mathrm{X}$ & & $\mathrm{X}$ & $\mathrm{X}$ & $\mathrm{X}$ & $\mathrm{X}$ & $\mathrm{X}$ ? & & $>1000^{\circ} \mathrm{C}$ \\
\hline PL 24-15 & 1 (Gradac II-III) & $\mathrm{X}$ & & moderate & $\mathrm{X}$ & $\mathrm{X}$ & & & $\mathrm{X}$ & & & & & $<900{ }^{\circ} \mathrm{C}$ \\
\hline PL 24-23 & 1 (Gradac II-III) & & & moderate & $\mathrm{X}$ & $\mathrm{X}$ & & $\mathrm{X}$ & & $\mathrm{X}$ & & $X$ & & $>1000^{\circ} \mathrm{C}$ \\
\hline PL 24-32 & 1 (Gradac II-III) & & & weak & $X$ & $\mathrm{X}$ & & & $\mathrm{X}$ & & & & & $<900^{\circ} \mathrm{C}$ \\
\hline PL 24-34 & 1 (Gradac II-III) & & & moderate & $\mathrm{X}$ & $\mathrm{X}$ & & & $\mathrm{X}$ ? & $\mathrm{X}$ ? & & & & $<900^{\circ} \mathrm{C}$ \\
\hline PL 24-54 & 1 (Gradac II-III) & & & absent & $\mathrm{X}$ & $\mathrm{X}$ & & & $\mathrm{X}$ & & & & & $<900^{\circ} \mathrm{C}$ \\
\hline PL 24-70 & 1 (Gradac II-III) & $\mathrm{X}$ & & weak & $\mathrm{X}$ & $\mathrm{X}$ & & & $\mathrm{X}$ & & & & & $<900^{\circ} \mathrm{C}$ \\
\hline PL 24-73 & 1 (Gradac II-III) & & & absent & $\mathrm{X}$ & $\mathrm{X}$ & & & $\mathrm{X}$ & & & & & $<900^{\circ} \mathrm{C}$ \\
\hline PL 24-74 & 1 (Gradac II-III) & & & absent & $\mathrm{X}$ & $\mathrm{X}$ & & & $\mathrm{X}$ & & & & & $<900^{\circ} \mathrm{C}$ \\
\hline
\end{tabular}




\begin{tabular}{|c|c|c|c|c|c|c|c|c|c|c|c|c|c|c|}
\hline Sample & $\begin{array}{c}\text { Chronological } \\
\text { Horizon }\end{array}$ & $D B$ & $G P$ & $\begin{array}{l}\text { Optical } \\
\text { Activity }\end{array}$ & $Q t z$ & $F s p$ & $C c$ & $A m$ & III & Msc & $\mathrm{Hem}$ & $\mathrm{Cri}$ & $S p l$ & Temp \\
\hline PL 24-75 & 1 (Gradac II-III) & & & absent & $X$ & $\mathrm{X}$ & & & $X$ & & & & & $<900^{\circ} \mathrm{C}$ \\
\hline PL 24-83 & 1 (Gradac II-III) & & & absent & $\mathrm{X}$ & $\mathrm{X}$ & $\mathrm{X}$ & & $\mathrm{X}$ & & & & & $<900{ }^{\circ} \mathrm{C}$ \\
\hline PL 24-101 & $2($ Gradac I $)$ & $X$ & & weak & $\mathrm{X}$ & $\mathrm{X}$ & & & $\mathrm{X}$ & & & & & $<900^{\circ} \mathrm{C}$ \\
\hline PL 24-103 & 2 (Gradac I) & & $X$ & moderate & $\mathrm{X}$ & $\mathrm{X}$ & & & $\mathrm{X}$ & & & & & $<900^{\circ} \mathrm{C}$ \\
\hline PL 24-107 & 2 (Gradac I) & $X$ & & weak & $\mathrm{X}$ & $\mathrm{X}$ & & & $\mathrm{X}$ & & & & & $<900{ }^{\circ} \mathrm{C}$ \\
\hline PL 24-113 & 2 (Gradac I) & & & high & $\mathrm{X}$ & $\mathrm{X}$ & & $\mathrm{X}$ & $\mathrm{X}$ & & & & & $<900^{\circ} \mathrm{C}$ \\
\hline PL 24-124 & 2 (Gradac I) & & $\mathrm{X}$ & weak & $\mathrm{X}$ & $\mathrm{X}$ & & & $\mathrm{X}$ & & & & & $<900^{\circ} \mathrm{C}$ \\
\hline PL 21-129 & 2 (Gradac I) & & $\mathrm{X}$ & weak & $\mathrm{X}$ & $\mathrm{X}$ & & & $\mathrm{X}$ & & & & & $<900^{\circ} \mathrm{C}$ \\
\hline PL 24-132 & 2 (Gradac I) & $\mathrm{X}$ & & weak & $\mathrm{X}$ & $\mathrm{X}$ & & & $\mathrm{X}$ & & & & & $<900^{\circ} \mathrm{C}$ \\
\hline PL 24-145 & 2 (Gradac I) & $\mathrm{X}$ & & weak & $\mathrm{X}$ & $\mathrm{X}$ & & & $\mathrm{X}$ & & & & & $<900^{\circ} \mathrm{C}$ \\
\hline PL 24-157 & 3 (Gradac I) & $X$ & & weak & $\mathrm{X}$ & $\mathrm{X}$ & $\mathrm{X}$ & & $\mathrm{X}$ & & & & & $<900^{\circ} \mathrm{C}$ \\
\hline PL 24-161 & 3 (Gradac I) & $\mathrm{X}$ & & weak & $\mathrm{X}$ & $\mathrm{X}$ & & & $X$ & & & & & $<900^{\circ} \mathrm{C}$ \\
\hline PL 24-179 & 3 (Gradac I) & & & weak & $\mathrm{X}$ & $\mathrm{X}$ & & & $\mathrm{X}$ & & & & & $<900^{\circ} \mathrm{C}$ \\
\hline PL 24-186 & 3 (Gradac I) & $\mathrm{X}$ & & moderate & $\mathrm{X}$ & $\mathrm{X}$ & & & $\mathrm{X}$ & & & & & $<900^{\circ} \mathrm{C}$ \\
\hline PL 24-204 & 3 (Gradac I) & $\mathrm{X}$ & & weak & $\mathrm{X}$ & $\mathrm{X}$ & & & $\mathrm{X}$ & & & & & $<900^{\circ} \mathrm{C}$ \\
\hline PL 24-209 & 4 (B2) & $X$ & & weak & $\mathrm{X}$ & $X$ & & & $X$ & & & & & $<900^{\circ} \mathrm{C}$ \\
\hline PL 24-211 & 4 (B2) & $X$ & & moderate & $\mathrm{X}$ & $\mathrm{X}$ & & $X$ & $\mathrm{X}$ & & & & & $<900^{\circ} \mathrm{C}$ \\
\hline PL 24-215 & 2 (Gradac I) & & $X$ & weak & $\mathrm{X}$ & $X$ & & & $X$ & & & & & $<900^{\circ} \mathrm{C}$ \\
\hline PL 24-247 & 3 (Gradac I) & & $\mathrm{X}$ & weak & $\mathrm{X}$ & $\mathrm{X}$ & & & $\mathrm{X}$ & & & & & $<900{ }^{\circ} \mathrm{C}$ \\
\hline PL 24-263 & 3 (Gradac I) & $\mathrm{X}$ & & weak & $\mathrm{X}$ & $\mathrm{X}$ & & & $\mathrm{X}$ & & & & & $<900^{\circ} \mathrm{C}$ \\
\hline PL 24-267 & 3 (Gradac I) & $\mathrm{X}$ & & high & $\mathrm{X}$ & $\mathrm{X}$ & & & $\mathrm{X}$ & & & & & $<900{ }^{\circ} \mathrm{C}$ \\
\hline PL 24-275 & 4 (B2) & $X$ & & absent & $\mathrm{X}$ & $X$ & $X$ & & $X$ & & & & & $<900^{\circ} \mathrm{C}$ \\
\hline PL 24-287 & $4(\mathrm{~B} 2)$ & & & moderate & $\mathrm{X}$ & $\mathrm{X}$ & & & $\mathrm{X}$ & & & & & $<900{ }^{\circ} \mathrm{C}$ \\
\hline PL 24-288 & 4 (B2) & $X$ & & high & $\mathrm{X}$ & $X$ & & & $X$ & & & & & $<900^{\circ} \mathrm{C}$ \\
\hline PL 24-299 & 4 (B2) & & & high & $\mathrm{X}$ & $\mathrm{X}$ & & & $\mathrm{X}$ & & & & & $<900^{\circ} \mathrm{C}$ \\
\hline PL 24-303 & 4 (B2) & $X$ & & weak & $\mathrm{X}$ & $\mathrm{X}$ & & & $\mathrm{X}$ & & & & & $<900^{\circ} \mathrm{C}$ \\
\hline PL 24-307 & 4 (B2) & $\mathrm{X}$ & & weak & $\mathrm{X}$ & $\mathrm{X}$ & & & $\mathrm{X}$ & & & & & $<900^{\circ} \mathrm{C}$ \\
\hline PL 24-313 & $5(\mathrm{~A} 2-\mathrm{B} 1)$ & & & weak & $\mathrm{X}$ & $\mathrm{X}$ & & & $\mathrm{X}$ & & & & & $<900^{\circ} \mathrm{C}$ \\
\hline PL 24-314 & $5(\mathrm{~A} 2-\mathrm{B} 1)$ & $X$ & & weak & $\mathrm{X}$ & $X$ & & & $X$ & & & & & $<900^{\circ} \mathrm{C}$ \\
\hline PL 24-315 & $5(\mathrm{~A} 2-\mathrm{B} 1)$ & $X$ & & weak & $\mathrm{X}$ & $X$ & & $X$ & $X$ & & & & & $<900^{\circ} \mathrm{C}$ \\
\hline PL 24-318 & 5 (A2-B1) & & & weak & $X$ & $X$ & $X$ & & $X$ & & & & & $<900^{\circ} \mathrm{C}$ \\
\hline PL 24-319 & $5(\mathrm{~A} 2-\mathrm{B} 1)$ & $X$ & & moderate & $\mathrm{X}$ & $\mathrm{X}$ & & $\mathrm{X}$ & $X$ & & & & & $<900^{\circ} \mathrm{C}$ \\
\hline PL 24-320 & $5(\mathrm{~A} 2-\mathrm{B} 1)$ & $X$ & & weak & $\mathrm{X}$ & $X$ & & & $X$ & & & & & $<900^{\circ} \mathrm{C}$ \\
\hline PL 24-323 & $5(\mathrm{~A} 2-\mathrm{B} 1)$ & & & moderate & $X$ & $\mathrm{X}$ & & & $X$ & & & & & $<900^{\circ} \mathrm{C}$ \\
\hline PL 24-324 & $5(\mathrm{~A} 2-\mathrm{B} 1)$ & & & absent & $\mathrm{X}$ & $X$ & & & $\mathrm{X}$ & & & & & $<900^{\circ} \mathrm{C}$ \\
\hline PL 24-328 & $5(\mathrm{~A} 2-\mathrm{B} 1)$ & & & moderate & $\mathrm{X}$ & $\mathrm{X}$ & & & $\mathrm{X}$ ? & $\mathrm{X}$ ? & & & & $<900^{\circ} \mathrm{C}$ \\
\hline PL 24-329 & $5(\mathrm{~A} 2-\mathrm{B} 1)$ & $\mathrm{X}$ & & moderate & $\mathrm{X}$ & $\mathrm{X}$ & & & $\mathrm{X}$ & & & & & $<900^{\circ} \mathrm{C}$ \\
\hline PL 24-331 & $5(\mathrm{~A} 2-\mathrm{B} 1)$ & $X$ & & weak & $\mathrm{X}$ & $\mathrm{X}$ & & & $\mathrm{X}$ & & & & & $<900^{\circ} \mathrm{C}$ \\
\hline PL 24-332 & 5 (A2-B1) & $X$ & & weak & $\mathrm{X}$ & $X$ & & & $\mathrm{X}$ & & & & & $<900^{\circ} \mathrm{C}$ \\
\hline PL 24-333 & 5 (A2-B1) & & & moderate & $X$ & $X$ & & & $X$ & & & & & $<900^{\circ} \mathrm{C}$ \\
\hline
\end{tabular}

Table 4. Summary of the XRD results ( $\mathrm{DB}=$ dark-burnished; $\mathrm{GP}=$ graphite-painted).

The presence of clay minerals indicates that the maximum firing temperature of the majority of the analysed pottery samples must have been below $850-900{ }^{\circ} \mathrm{C}$, at which their crystalline structure is destroyed (Kulbicki, 1958; Maggetti, 1982). In addition, some samples contain calcite $\left(\mathrm{d}=3.04 \AA\right.$ ), which decomposes between $750-850^{\circ} \mathrm{C}$ (Maggetti, 1982; Maritan, 2004). 

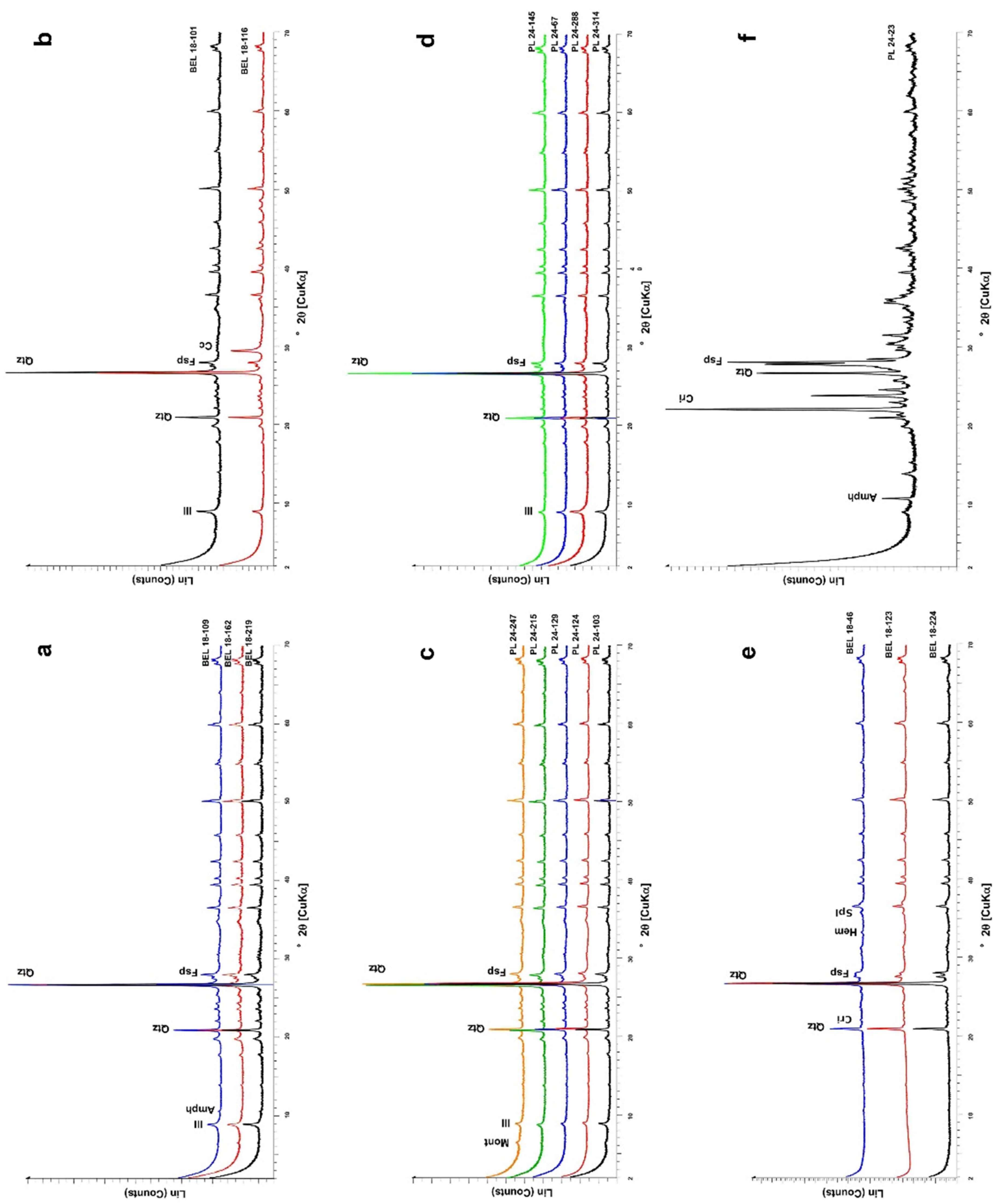

Figure 5. X-ray diffractograms of selected pottery sherds from the Vinča culture sites of Belovode and Pločnik in this study. Mineral abbreviations: $\mathrm{Amph}=$ amphibole; $\mathrm{Cc}=$ calcite; $\mathrm{Cri}=$ cristobalite Hem = hematite; $\mathrm{Ill}=$ illite; Fsp = feldspar; Mont = montmorillonite; $\mathrm{Qtz}=$ quartz; Spl= spinel (a: dark-burnished pottery from Belovode, fabric A2; b) dark-burnished pottery from Belovode, fabric B2; c) dark-burnished pottery from Pločnik, fabric A2; d) graphite-painted pottery from Pločnik, fabric A2; e) and f) sherds from Belovode and Pločnik containing high temperatures phases). 
The mineralogical composition of the ceramics suggests that most sherds, including the darkburnished and graphite-painted pottery, were probably fired to a maximum temperature of between $750-850^{\circ} \mathrm{C}$. However, a few sherds from Belovode and Pločnik (Figure 5 e and f) contain high temperature neo-phases including cristobalite and spinel, recognisable from a broad reflection at $\mathrm{d}=2.44 \AA$ and $\mathrm{d}=4.14 \AA$. These samples do not show presence of clay minerals, but contain hematite, which was not detected in any other of the sherds analysed. In non-calcareous clay pastes fired under oxidising conditions this mineral could begin to nucleate at about $700{ }^{\circ} \mathrm{C}$. It may be below the limits of detection in the majority of samples given their relatively low concentration of iron (c. 6\% $\mathrm{Fe}_{2} \mathrm{O}_{3}$ ) (Amicone, 2017, pp. 161-170 and 199-208) and their lower firing temperature.

\begin{tabular}{|c|c|c|c|c|c|c|}
\hline Sample & $\begin{array}{c}\text { Chronological } \\
\text { Horizon }\end{array}$ & $D B$ & $G P$ & Fabric & Refiring & $\begin{array}{c}\text { Degree of } \\
\text { Vitrification }\end{array}$ \\
\hline BEL 46 & $1(\mathrm{C}-\mathrm{D})$ & & & BEL-A1 & & $\mathrm{C}$ \\
\hline BEL 68 & $1(\mathrm{C}-\mathrm{D})$ & $\mathrm{X}$ & & BEL-A1 & $\mathrm{X}$ & IV \\
\hline BEL 94 & $1(\mathrm{C}-\mathrm{D})$ & $\mathrm{X}$ & & BEL-A2 & $\mathrm{X}$ & IV \\
\hline BEL 95 & $1(\mathrm{C}-\mathrm{D})$ & $\mathrm{X}$ & & BEL-A1 & $\mathrm{X}$ & IV \\
\hline BEL 115 & $1(\mathrm{C}-\mathrm{D})$ & & & BEL-B1 & & IV \\
\hline BEL 116 & $1(\mathrm{C}-\mathrm{D})$ & & & BEL-B1 & & IV \\
\hline BEL 118 & $1(\mathrm{C}-\mathrm{D})$ & $\mathrm{X}$ & & BEL-A2 & $\mathrm{X}$ & IV \\
\hline BEL 123 & $1(\mathrm{C}-\mathrm{D})$ & & & BEL-A1 & & $\mathrm{C}$ \\
\hline BEL 132 & $1(\mathrm{C}-\mathrm{D})$ & & & BEL-B1 & $\mathrm{X}$ & IV \\
\hline BEL 224 & 2 (Gradac-C) & & & BEL-A1 & & $\mathrm{C}$ \\
\hline BEL 288 & $4(\mathrm{~A})$ & & & BEL-F & & IV \\
\hline BEL 295 & $4(\mathrm{~A})$ & & & BEL-A1 & & IV \\
\hline BEL 303 & 5 (Starčevo/A) & & & BEL-C & & IV \\
\hline BEL 334 & $5($ Starčevo/A) & & & BEL-C & & IV \\
\hline PL 21-21 & 3 (Gradac I) & $\mathrm{X}$ & & PL-A2 & & IV \\
\hline PL 21-47 & 1 (Gradac II-III) & $X$ & & PL-A2 & $\mathrm{X}$ & IV \\
\hline PL 21-49 & 1 (Gradac II-III) & $\mathrm{X}$ & & PL-A2 & $\mathrm{X}$ & IV \\
\hline PL 21-55 & 1 (Gradac II-III) & $\mathrm{X}$ & & PL-A2 & $X$ & IV \\
\hline PL 20-69 & 1 (Gradac II-III) & & & PL-E & & IV \\
\hline PL 24-23 & 1 (Gradac II-III) & & & PL-F & & $\mathrm{V}$ \\
\hline PL 24-83 & 1 (Gradac II-III) & & & PL-A1 & & IV \\
\hline PL 24-103 & $2($ Gradac I $)$ & & $\mathrm{X}$ & PL-A1 & & IV \\
\hline PL 24-124 & 2 (Gradac I) & & $\mathrm{X}$ & PL-A2 & & IV \\
\hline PL 24-129 & 2 (Gradac I) & & $X$ & PL-A2 & & IV \\
\hline PL 24-157 & 3 (Gradac I) & $X$ & & PL-A2 & $\mathrm{X}$ & IV \\
\hline PL 24-161 & 3 (Gradac I) & $\mathrm{X}$ & & PL-A2 & $\mathrm{X}$ & IV \\
\hline PL 24-215 & 2 (Gradac I) & & $X$ & PL-A2 & & IV \\
\hline PL 24-247 & 3 (Gradac I) & & $X$ & PL-A1 & & IV \\
\hline PL 24-303 & $4(\mathrm{~B} 2)$ & $X$ & & PL-A1 & & IV \\
\hline PL 24-313 & $5(\mathrm{~A} 2-\mathrm{B} 1)$ & & & PL-A1 & & IV \\
\hline
\end{tabular}

Table 5. Summary of the results of the SEM analysis (IV= initial vitrification $750-800{ }^{\circ} \mathrm{C}$; $\mathrm{V}=$ extensive vitrification $900-950{ }^{\circ} \mathrm{C}$; $\mathrm{C}=$ continuous vitrification $1000-1050{ }^{\circ} \mathrm{C}$; $\mathrm{DB}=$ darkburnished; GP=graphite-painted). 

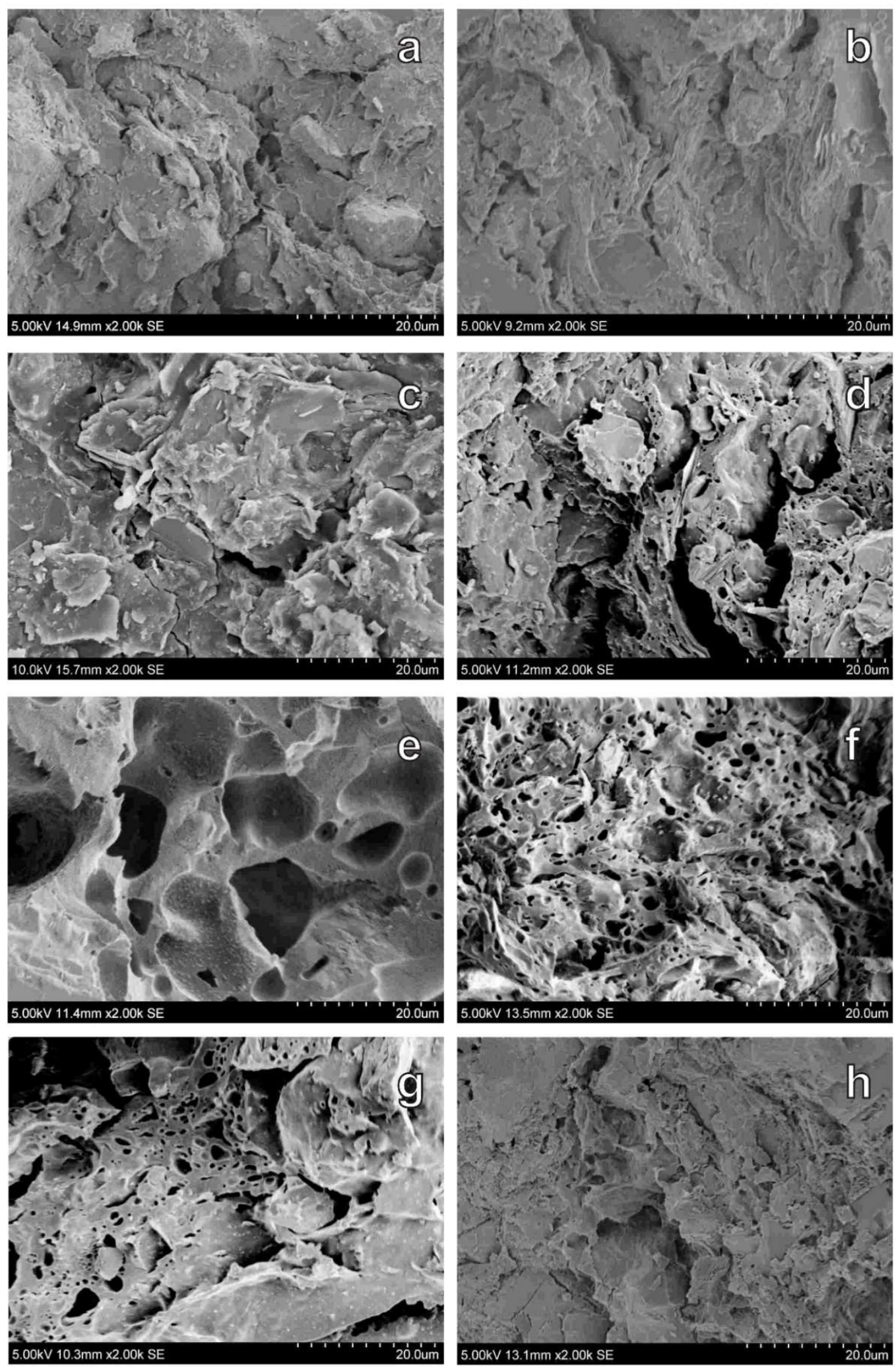

Figure 6. Vitrification microstructure of selected pottery sherds from the Vinča culture sites of Belovode and Pločnik, as seen in the SEM under secondary electron imaging: a) BEL 118; b) PL 21-55; c) PL 24-215 (graphite-painted); d) PL 24-247 (graphite-painted); e) BEL 46; f) BEL 123; g) BEL 224; h) BEL 24-23). See table 5 for interpretation of vitrification stage and firing temperatures. 

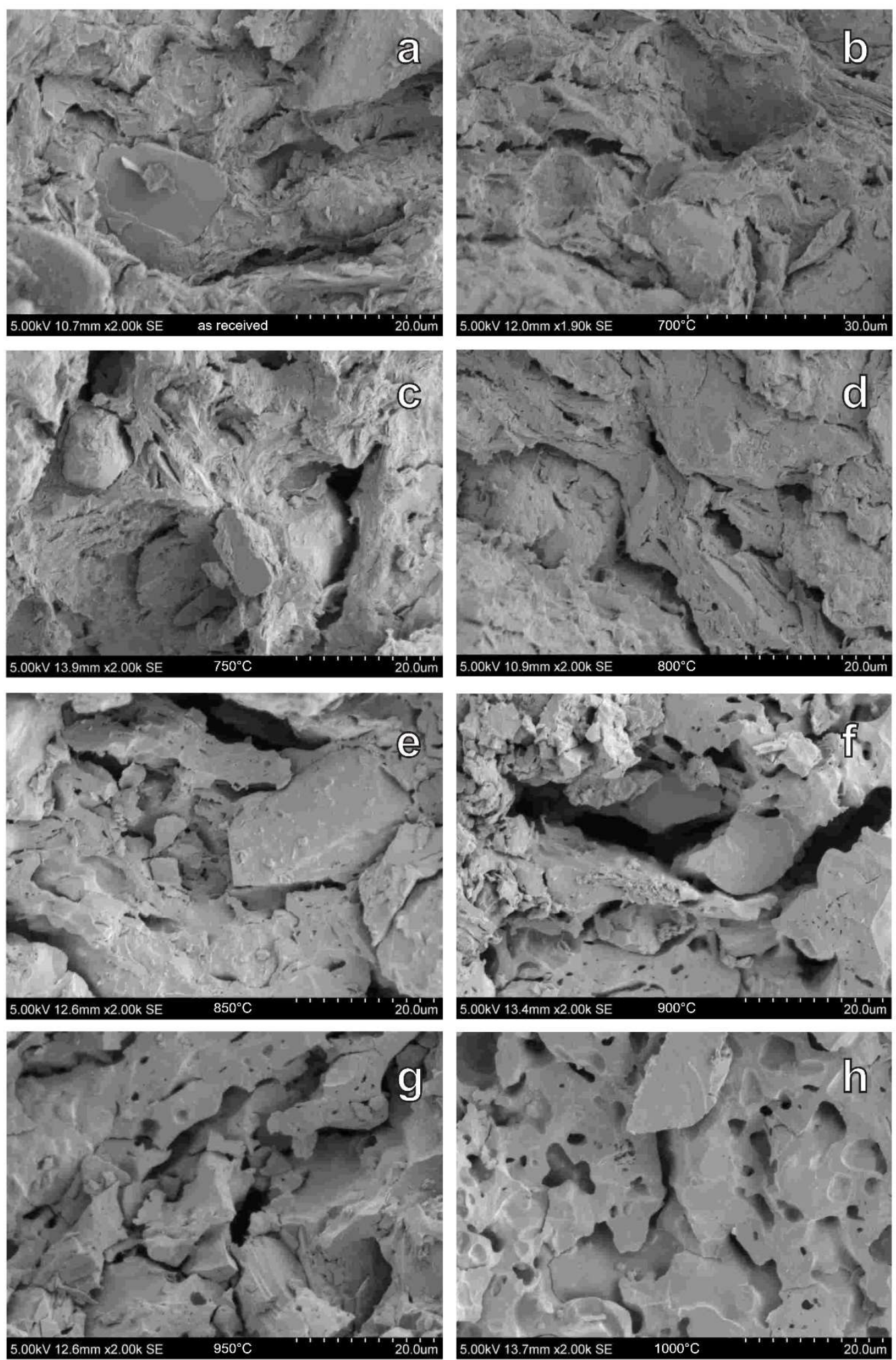

Figure 7. Vitrification microstructure as seen in the SEM under secondary electron imaging of a dark-burnished (BEL 94) sherd from the Vinča culture site of Belovode, refired in reducing atmosphere at different temperatures: a) as received; b) $700{ }^{\circ} \mathrm{C}$; c) $750{ }^{\circ} \mathrm{C}$; d) $800{ }^{\circ} \mathrm{C}$; e) 850 ${ }^{\circ} \mathrm{C}$; f) $900{ }^{\circ} \mathrm{C}$; g) $950{ }^{\circ} \mathrm{C}$; h) $1000{ }^{\circ} \mathrm{C}$. 
The microstructure of thirty samples examined in fresh fracture in the SEM indicates that initial vitrification had taken place (Table 5; Figure 6). This is compatible with an equivalent firing temperature of $800-850{ }^{\circ} \mathrm{C}$ in an oxidising atmosphere and $750-800{ }^{\circ} \mathrm{C}$ in a reducing atmosphere in both calcareous and non-calcareous clay (Maniatis and Tite, 1981, p. 61). One sherd decorated with graphite (PL 24-247) revealed a microstructure more vitrified and with fine bloating pores that is compatible with more reducing conditions (Maniatis and Tite, 1981, p. 61). The re-fired dark-burnished sherds indicated a change in the vitrification microstructure between 750-800 ${ }^{\circ} \mathrm{C}$ (Figure 7), thus confirming the above firing temperature estimate. Additionally, a few samples from both sites that contain high temperature neo-phases exhibit an extensive or continuous degree of vitrification with or without bloating pores (Figure 6 eh), and could have been fired as high as $1000{ }^{\circ} \mathrm{C}$. These sherds were not dark-burnished or graphite-painted and were either recovered from possible destruction layers or were examples of so-called 'chimneys' that were initially interpreted as connected to smelting activities. The 'chimney' theory was discarded after chemical analysis of these objects showed no contamination with metallic elements (Radivojević and Kuzmanović-Cvetković, 2014).
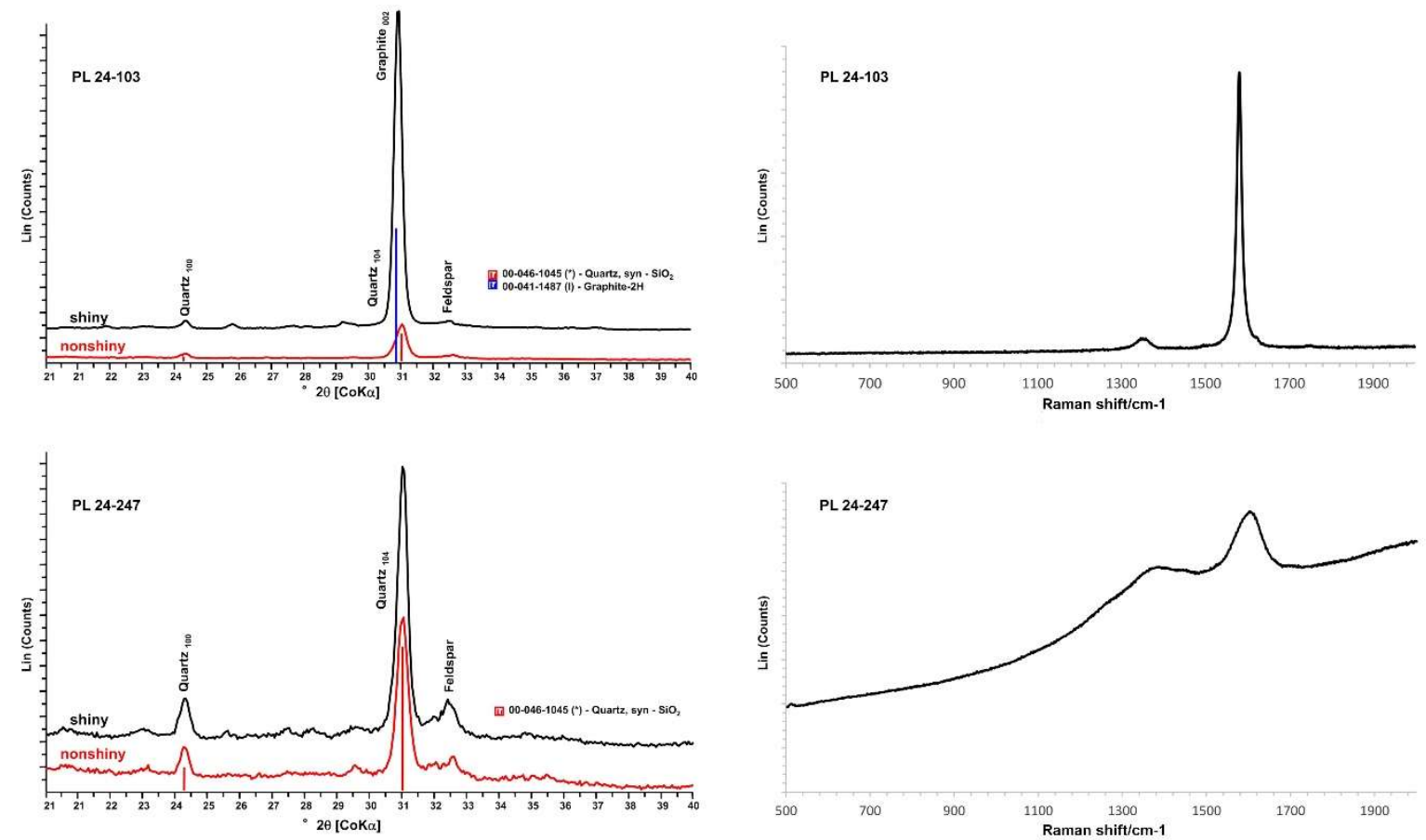

Figure 8. Diffractograms revealing the mineralogical composition of the surface of selected graphite-painted pottery sherds from the Vinča culture sites of Pločnik in this study, collected via $\mu-\mathrm{XRD}^{2}$ (on the left) and $\mu$-Raman (on the right).

Analysis of the surfaces of the graphite-painted sherds from Pločnik via $\mu-X_{R D}^{2}$ indicates that both the undecorated and decorated areas contain quartz. However, in the diffractograms recorded on the decoration there is in most cases a small shift in the position of the quartz 104 peak and significant increase in intensity that seems to signify the presence of graphite (Figure 9). The latter has its main peak at almost the same angle as quartz, hindering secure discrimination between the two phases (Letsch and Noll, 1978, p. 1983). Analysis via $\mu$-Raman spectroscopy (Figure 8) confirmed that the graphite decoration in four specimens analysed consists of perfect crystalline and well textured flaky graphite that is likely to come from a natural source. In one sample, however, $\mu$-Raman analysis suggests that the decoration consists of poorly 
crystalline carbon black (Figure 8). This is the same type of carbon black pigment that is found on the undecorated dark-burnished ceramic.

\section{Discussion}

No secure evidence exists to provide information about the firing technology of Vinča pottery, such as kilns, workshops or wasters (Vuković, 2018), and it is not possible to exclude that ceramics were fired in bonfires or pits (Amicone and Berthold, 2019; Svoboda et al., 2004/2005; Vuković, 2018), which often leave no trace in the archaeological record. Nevertheless, the results of this archaeometric study on the fired pottery sherds together with the recent literature mentioned above helps to identify important aspects of Vinča ceramic pyrotechnology.

\subsection{Reconstructing black pottery production}

The surface colour of dark-burnished pottery could have been achieved in several possible ways, including iron reduction, manganese black or the carbon black smudging technique. Mineralogical analysis via XRPD analysis did not record the presence of magnetite nor manganese on the surface of any of the analysed sherds from either site, thus ruling out the first two methods of producing black pottery (see above, 1.2). However, carbon was detected on the surface of several dark-burnished sherds from both Pločnik and Belovode via $\mu$-Raman analysis, suggesting that their lustrous black surfaces were the result of the carbon black smudging technique.

As most of the samples have a reddish core and dark margins, it is possible to propose a twostep firing procedure in which vessels were initially fired in an oxygen-rich atmosphere at which the maximum firing temperature was achieved and sintering started to take place, giving the ceramics their rigidity. Following this, as the temperature was decreasing towards the end of the firing process, a reducing atmosphere was created, probably by covering the firing installation and possibly adding some sort of readily combustible fine-textured organic material. This second step would have resulted in an increase in smoke and the deposition of carbon on the surface of the pottery. The absence of magnetite in the sherds indicates that the reducing phase was rather short and probably took place at the end of the firing. This is also indicated by the reddish core of the majority of the samples, suggesting a rather superficial penetration of carbon into the body of these vessels. Variation in the colour or the dark finish from black through light grey and yellow suggests that potters may not have been able to entirely control the firing atmosphere during the smudging phase. The presence of a small amount of free oxygen would have burnt off some of the carbon or prevented its deposition in places.

Graphite-painted Vinča pottery may also have been fired in a two-step firing procedure, with a longer reducing process given the relatively homogeneous dark to light grey colour of most of these sherds in thin section. The reducing phase would have started earlier in the process than in the production of black-burnished pottery, certainly before the initial oxidising phase would have reached a temperature of about $700{ }^{\circ} \mathrm{C}$, at which point the graphite would have begun to burn off relatively quickly (Kreiter et al., 2013, p. 176; 2014). Despite the predominantly reducing conditions for most of the firing, sintering has been achieved, with estimated firing temperatures of most samples between 750 and $800{ }^{\circ} \mathrm{C}$; the presence of bloating pores in one sherd (Figure 6 d) indicated more reducing conditions (Maniatis and Tite, 1975). 
Analysis of the 'graphite' painted decoration of one out of five selected samples using $\mu-\mathrm{XRD}^{2}$ and $\mu$-Raman revealed that it was actually coated with a type of artificial carbon black pigment which achieved a very similar metallic lustre to mineral graphite (the 'Glanzkohlenstoff' of Letsch and Noll, 1978; 1983), where the distinction from graphite painting is difficult to make by naked eye. This finding suggests that the same 'graphite' decorative effect on Vinča pottery could have been produced using several alternative technological processes that well show the technological advancements reached by the potters. Equally, it exhibits innovative solutions to decorate the pottery with metallic lustre, which also confirms distinctive metal-like appearance as one of the linking components between the metal and pottery technologies in the presented case.

Overall, the combination of petrographic, XRPD and SEM analyses of the Belovode and Pločnik sherds suggest that they were fired at a range of temperatures between $750{ }^{\circ} \mathrm{C}$ and 900 ${ }^{\circ} \mathrm{C}$, with the majority of samples falling between 750 and $800{ }^{\circ} \mathrm{C}$. Firing temperatures did not exceed c. $900{ }^{\circ} \mathrm{C}$ on a regular basis and only the three so-called 'chimney' fragments (which were not dark-burnished or graphite-painted) and few other sherds from possible destruction layers were heated to temperatures above $1000^{\circ} \mathrm{C}$.

\subsection{Deconstructing the link between pottery production and metallurgy}

Based upon the above reconstruction of Vinča culture ceramic pyrotechnology, it is possible to re-examine its purported link to the emergence of copper smelting in the Balkans, prominently proposed by Renfrew (1969), Kaiser et al. (1986), and others. In order to achieve the various decorative finishes applied to Vinča ceramics, potters were able to control the redox conditions of the firing process. The production of both dark-burnished and graphite-painted pottery would have been achieved by opening and closing the firing installation and thus varying the air to fuel ratio. Potters also seem to have added relatively moist organic matter, such as straw and leaves which combusted quickly and used up free oxygen while depositing soot, as well as perhaps ash.

This manipulation of firing atmosphere, particularly the ability to obtain and sustain reducing conditions, could have been an important precursor to the development of early metallurgy, which requires a predominantly reducing atmosphere to smelt copper from its ore before more oxidising conditions are introduced to reach the melting point of pure copper. It is certainly possible to envisage the transfer of this knowledge of manipulating and varying temperatures and redox conditions from ceramic production to another technological domain such as metallurgy.

The term invention is often defined as the discovery of a new idea, a new material or a new process (e.g. Radivojević, 2015; Renfrew, 1978). This can be a completely new product (Weber et al., 1993), or, alternatively, involve the recombination of pre-existing technological components for a new purpose (Fleming and Sorenson, 2004; Henrich, 2010), as appears to have been the case here. Even if the matter is still debated (e.g. Kaiser, 1984; Vuković, 2011; Spataro, 2018) and it is not possible to exclude that a certain degree of specialisation in pottery production existed among Vinča potters, no convincing arguments have been brought in thus far that demonstrated that this craft was a highly specialised activity carried out by professional figures that had privileged access to resources and technology. The stated argument is further corroborated by the fact that metalworking during its inception was most probably a nonspecialised household activity, as already suggested in Radivojević and Rehren (2016). According to this scenario, craft knowledge was not segregated within certain specialised 
groups and could have been easily transferred from pottery making to other technological domains or vice versa.

The wider appearance of graphite decoration in particular seems to be contemporary with the emergence of metallurgy during the start of the fifth millennium BC across the Balkans (Bailey, 2000, p. 227, Vajsov, 2007) and requires a similarly strongly reducing atmosphere for much of the firing cycle as is required in copper smelting, as presented above. Based on current dating evidence placing graphite painted decoration in Pločnik at the onset of the fifth millennium $\mathrm{BC}$, it is possible to suggest a parallel development or even reverse trajectory of transmission in which the production of a graphite-painted decoration was influenced by early metallurgy and they were both benefitting from the pre-existing experience with dark-burnished pottery.

Nevertheless, while graphite-painted decoration and metallurgy emerge in the Balkans at broadly the same period it is important to bear in mind that the current evidence seems to suggest that the earliest emergence of the two are geographically unrelated, with graphitepainted pottery probably first appearing in the Struma Valley (Vajsov, 2007), outside the Vinča Culture (Fig.1), which was home to the earliest metallurgy (Radivojević et al., 2010).

At the same time, as a rare naturally occurring substance with a strong visual appeal, the use of graphite by potters across such a wide region could indicate that they participated in or benefitted from specialist trade networks; these networks may not have been the same as those of copper supply for the mentioned sites (Radivojević and Grujić, 2018) though they must have required similar cooperation patterns to meet the (high) demand.

Given all the above, to investigate better these themes more work focused on the study of graphite deposits in the Balkans, graphite circulation and on the origin and technological development of this decorative technique needs to be done.

\section{Conclusion}

The results of the present study suggest that the potters in the sites of Belovode and Pločnik were not normally using firing temperatures in excess of $750-800^{\circ} \mathrm{C}$, which were sufficient to produce functional pots, but not enough to melt copper metal. This clearly contrasts with the much higher temperatures proposed in early previous studies such as Frierman (1969; but see Kingery and Frierman, 1974) and Kaiser et al. (1986), and is instead more in line with the findings of Gardner (1978; 1979; 2003), Goleanu et al., (2005), , Maniatis and Tite (1981) Perišić et al. (2016), Spataro $(2014 ; 2017 ; 2018)$ and Yiouni $(1995 ; 2000 ; 2001)$. While the firing temperatures to which the analysed samples were subjected would have been sufficient for solid-state reduction of oxidic copper minerals to copper metal (Pollard et al., 1991, p. 133; see Radivojević et al., 2017 for a detailed discussion of this phenomenon from an experimental context), the pottery firing installations would not have supplied enough energy to effectively smelt copper from its ore, or facilitate physical change from solid to liquid metal. This requires not only sufficiently reducing conditions, but a sustained temperature well in excess of 1000 ${ }^{\circ} \mathrm{C}$ to melt the micro-prills of copper metal formed at lower temperatures, and coagulate them to useable quantities of metal. Whilst it is possible that Vinča potters could have achieved higher maximum temperatures and energy levels within their firing installations, the analysis of sherds from Belovode and Pločnik do not record any clear evidence for this. The early overestimation of ceramic firing temperatures by previous authors appears to have subsequently been over-interpreted to explain the very early appearance of copper smelting in this region. Our own work, building on more recent moderate temperature estimates from various sites 
across the Balkans (see references above), expands them with a systematic study of a large number of samples from two key Vinča sites for the emergence of metallurgy. In conjunction with more recent dating evidence for the emergence of graphite-painted pottery (Vajsov, 2007) and early metallurgy (Radivojević and Kuzmanović-Cvetković, 2014), respectively, this now makes a chronological sequence of the two phenomena less likely, let alone a causal technological sequence of metallurgy emerging directly from the firing technology used to produce black pottery.

Nevertheless, the results of this study and the recent literature indicate that Vinča pottery firing technology shares some significant similarities with the pyrotechnology of copper smelting, namely the ability to exert sufficient control over redox atmosphere of the firing process to produce a consistently shiny black appearance of dark-burnished and graphite-painted pottery. Noteworthy, the technique that appears to have the strongest link with copper smelting is the graphite decoration, as it is the one that relies the most on a nuanced understanding of the balance of redox conditions and of the two-step principle of alternating between reduction and oxidation stages during firing. The latter applies to both graphite decorating and metal smelting, albeit in different order. With this in mind, the two crafts are likely to have been generally linked, making them 'close cousins' rather than one being the precursor to the other.

Tantalisingly, graphite is also visually appealing as a lustrous black mineral, and as such may have been part of the same supply chain and conceptually included by early prospectors in the suite of black-and-green minerals that lies at the heart of the earliest metallurgy in the Balkans (Radivojević and Rehren, 2016). This supply chain is only one of the building blocks of this connection; the main output of aesthetically appealing materials with high brilliance certainly fits the practices of exceptional craftsmanship (Chapman, 2011) and even more importantly, the increased demand for it at the time.

\section{Acknowledgments}

The authors are indebted to all those who contributed to the archaeological excavation of Belovode and Pločnik settlements during the summer excavations seasons in 2012 and 2013. Financial support for this research has been generously provided by the Arts and Humanities Research Council (AHRC), the Institute for Archaeo-Metallurgical Studies (IAMS), and the Funds for Women Graduates (FfWG). We would like to thank Julka Kuzmanović-Cvetković, Gordana Grabez, Dusko Sljivar, and the National Museum in Belgrade for securing access to materials. We are also indebted to Enrica Bonato, Annette Flicker, Lars Heinze, Tobias Kiemle, Frieder Jakob Lauxmann, Neda Mirković-Marić, Miroslav Marić, Lionello Morandi, and Jugoslav Pendić for their help and feedback. Silvia Amicone and Christoph Berthold would like to express their gratitude to the Excellence Initiative of the Eberhard Karls Universität Tübingen and the Ministry for Science, Research and Art of Baden-Württemberg for their support during the preparation of this article. Constructive comments by reviewers and the editor helped us strengthen the paper, and are much appreciated. All remaining shortcomings are ours.

\section{Author contributions}

Silvia Amicone: conceptualisation, investigation, methodology, archaeometric analyses and their interpretation, writing (original draft). Miljana Radivojević: funding acquisition, project administration, conceptualisation, investigation, supervision, editing and reviewing (original draft). Patrick Quinn: investigation, methodology, supervision, validation, writing, editing and 
reviewing (original draft). Christoph Berthold: investigation, methodology, supervision (XRD and Raman analyses), validation, editing and reviewing (methods and results sections). Thilo Rehren: funding acquisition, conceptualisation, investigation, supervision, editing and reviewing (final draft).

\section{References}

Amicone, S. 2017. Pottery Technology at the Dawn of the Metal Age: A view from Vinča Culture. Unpublished Ph.D. thesis, University College London.

Amicone, S. and Berthold, C. 2019. Playing with Fire: Exploring Prehistoric Ceramic Pyrotechnology in the Balkans. Paper presented at Trial by Fire - An interdisciplinary conference about the transformation power of fire (17-18.05.2019), University College London.

Bailey, D. W. 2000. Balkan Prehistory. London/New York: Routledge.

Bentsen, S. E. 2014. Using pyrotechnology: Fire-related features and activities with focus on the African Middle Stone Age. Journal of Archaeological Research 22, 141-175.

Berthold, C., Keuper, M. and Bente, K. 2015. Non-destructive X-ray microdiffraction coupled with $\mu$-Raman spectroscopy and $\mu$ X-ray fluorescence. In: T. Gluhak, S. Greiff, K. Kraus, M. Prange (eds), METALLA Sonderheft 7. Bochum: Deutsches Bergbau-Museum, 24-26.

Berthold, C. and Mentzer, S. M. 2017. X-ray microdiffraction. In: C. Nicosia and G. Stoops (eds), Archaeological Soil and Sediment Micromorphology. Hoboken, NJ: John Wiley \& Sons, Ltd, 417-429.

Bonga, L. 2013. Late Neolithic Pottery from Mainland Greece, ca. 5,300-4,300 BC. Unpublished Ph.D. thesis, Temple University Graduate Board.

Breunig, P. 1987. ${ }^{14}$ C-Chronologie des vorderasiatischen, südost- und mitteleuropäischen Neolithikums. Köln: Böhlau.

Chapman, J. 1977. The Balkans in the Fifth and Fourth Millennia B.C. with Special Reference to Social and Economic Problems in the Vinča Culture. Unpublished Ph.D. thesis, University of London.

Chapman, J. 1981. Vinča Culture of South-East Europe: Studies in Chronology, Economy and Society. Oxford: British Archaeological Reports.

Chapman, J. 2006. Dark burnished ware as sign: ethnicity, aesthetics and categories in the later Neolithic of the central Balkans. In: N. Tasić and C. Grozdanov (eds), Homage to Milutin Garašanin. Belgrade: Serbian Academy of Sciences and Arts, 295-308.

Chapman, J. 2007. The elaboration of an aesthetic of brilliance and colour in the climax Copper Age. In: F. Lang, C. Reinholdt and J. Weilhartner (eds), Stephanos Aristeios. Archäologische Forschungen zwischen Nil und Istros. Festschrift für Stefan Hiller zum 65. Geburtstag. Wien: Phoibos, 64-74. 
Chapman, J. 2011. Enchantment and enchainment in later Balkan prehistory: Towards an aesthetic of precision and geometric order. In: A. Hadjikoumis, E. Robinson and S. Viner, (eds.), The Dynamics of Neolithisation in Europe. Studies in Honour of Andrew Sherratt. Oxbow Books: Oxford, 153-176.

Childe, V. G. 1936-37. Neolithic black ware in Greece and on the Danube. The Annual of the British School at Athens 37, 26-35.

Childe, V. G. 1944. Archaeological ages as technological stages. Journal of the Royal Anthropological Institute of Great Britain and Ireland 74, 7-24.

Craddock, P. T. 1995. Early Metal Mining and Production. Edinburgh: Edinburgh University Press.

Cuesta, A., Dhamelincour, P., Laureyns, J., Martinez-Alonso, A. and Tascón, J. M. D. 1998. Comparative performance of X-Ray diffraction and Raman microprobe techniques for the study of carbon materials. Journal of Materials Chemistry 8(12), 2875-2879.

Cuomo di Caprio, N. 2007. Ceramica in archeologia. Roma: L'Erma Bretschneider.

Ehrich, R. W. and Bankoff, H. A. 1992. East central and Southeastern Europe. In: R. W. Ehrich (ed.), Chronologies in Old World Archaeology. Chicago, IL: University of Chicago Press, 341375.

Faber, E., Day, P. M. and Kilikoglou, V. 2009. Fine-grained Middle Bronze Age polychrome ware from Crete: Combining petrographic and microstructural analysis. In: P. S. Quinn (ed.), Interpreting Silent Artefacts: Petrographic Analysis of Archaeological Ceramics. Oxford: Archaeopress, 139-156.

Fleming, L. and Sorenson, O. 2004. Science as a map in technological search. Strategic Management Journal 25, 909-928.

Frierman, J. 1969. The Balkan graphite ware (Appendix II). Proceedings of the Prehistoric Society 35, 42-44.

Garašanin, M. 1951. Hronologija vinčanske grupe (Chronology of the Vinča Group). Ljubljana: Univerza v Ljubljani.

Garašanin, M. 1954. Iz istorije mlađeg neolita u Srbiji i Bosni (History of the late Neolithic in Serbia and Bosnia). Glasnik Zemaljskog Muzeja, Sarajevo 9, 5-39.

Garašanin, M. 1979. Centralno balkanska zona (The central Balkans zone). In: A. Benac (ed.), Praistorija Jugoslavenskih Zemalja II (Prehistory of Yugoslav countries II). Sarajevo: Svjetlost, 79-212.

Garašanin, M. 1993. Zu den Problemen der Vinča-Gruppe in Rumänien. Balcanica 24, 7-20.

Garašanin, M. 1994/95. Die Gradac-Stufe der Vinča-Gruppe und der Beginn des Aeneolithikums. Dacia 38/39, 9-17. 
Gardner, E. J. 1978. The Pottery Technology of the Neolithic Period in South-Eastern Europe. Unpublished Ph.D. thesis, University of California at Los Angeles.

Gardner, E. J. 1979. Graphite painted ceramics. Archaeology 32(4), 18-23.

Gardner, E. J. 2003. Technical analysis of the ceramics / Appendix 7.1. Graphite painted pottery. In: E. S. Elster and C. Renfrew (eds), Excavations at Sitagroi. A Prehistoric Village in Northeast Greece: Vol. 2, The Final Report. Los Angeles, CA: Cotsen Institute of Archaeology, 283-298.

Gaul, J. H. 1948. The Neolithic Period in Bulgaria: Early Food Producing Cultures of Eastern Europe. Cambridge, MA: American School of Prehistoric Research.

Gimbutas, M. 1976. Neolithic Macedonia as Reflected by Excavation at Anza, Southeast Yugoslavia. Los Angeles, CA: Institute of Archaeology, University of California.

Goleanu, A., Marian, A., Gligor, M., Florescu, C. and Varvara, S. 2005. Chemical and structural features of the Neolithic ceramics from Vinča, Lumea Noua and Petresti cultures (Roumania). Revue Roumaine De Chimie 50, 939-949.

Gourdin, W. H. and Kingery, W. D. 1975. The beginnings of pyrotechnology: Neolithic and Egyptian lime plaster. Journal of Field Archaeology 2, 133-150.

He, B. B. 2018. Two-dimensional X-ray Diffraction, 2nd edition. Hoboken, N.J.: John Wiley \& Sons, Ltd.

Henrich, J. 2010. The evolution of innovation-enhancing institutions. In: M. J. O'Brien and S. J. Shennan (eds), Innovation in Cultural Systems. Contributions from Evolutionary Anthropology. Cambridge, MA: MIT Press, 99-120.

Holmberg, E. J. 1964. The appearance of Neolithic black burnished ware in mainland Greece. American Journal of Archaeology 68, 343-348

Jones, R. E. 1986. Greek and Cypriot Pottery: A Review of Scientific Studies. Athens: British School at Athens.

Jordan, P. and Zvelebil, M. 2009. Ceramics before Farming: The Dispersal of Pottery among Prehistoric Eurasian Hunter-Gatherers. Walnut Creek, CA: Left Coast Press.

Jovanović, B. 1971. Metallurgy in the Eneolithic Period in Yugoslavia. Belgrade: Archaeological Institute.

Jovanović, B. 1980. The origins of copper mining in Europe. Scientific American 242, 152167.

Jovanović, B. 1993/1994. Gradac phase in the relative chronology of the late Vinča culture. Starinar 43/44, 1-12. 
Jovanović, B. 2006. Gradac phase of the Vinča culture: Origin of a typological innovation. In: N. Tasić, and C. Grozdanov (eds), Homage to Milutin Garašanin. Belgrade: Serbian Academy of Sciences and Arts and Macedonian Academy of Sciences and Arts, 221-233.

Jovanović, B. and Ottaway, B. S. 1976. Copper mining and metallurgy in the Vinča group. Antiquity 50, 104-113.

Kaiser, T. 1984. Vinča Ceramics: Economic and Technological Aspects of late Neolithic Pottery Production in Southeast Europe. Unpublished Ph.D. thesis, University of California, Berkley.

Kaiser, T. and Lucius, W. 1989. Thermal expansion measurement and the estimation of prehistoric pottery firing techniques. In: G. Bronitsky (ed.), Pottery Technology: Ideas and Approaches. Boulder: Westview Press, 83-92.

Kaiser, T., Franklin, U. and Vitali, V. 1986. Pyrotechnology and Pottery in the Late Neolithic of the Balkans. In: J. S. Olin and M. J. Blackman (eds), Proceedings of the 24th International Archaeometry Symposium. Washington, DC: Smithsonian Institution, 85-94.

Kingery, W. D. and Frierman, J. D. 1974. The firing temperature of a Karanova sherd and inferences about southeast European Chalcolithic refractory technology. Proceedings of the Prehistoric Society 40, 204-205.

Kreiter, A., Bartus-Szöllösi, Sz., Bajnóczi, B., Azbej Havancsák, I., Tóth, M. and Szakmány, Gy. 2013. Ceramic technology and the materiality of Celtic graphitic pottery. In: M. E. Alberti and S. Sabatini (eds), Exchange Networks and Local Transformations. Interaction and Local Change in Europe and the Mediterranean from the Bronze Age to the Iron Age. Oxford: Oxbow, 169-179.

Kreiter, A., Czifra, S., Bendo, Z., Imre, J. E., Panczel, P. and Vaczi, G. 2014. Shine like metal: An experimental approach to understand prehistoric graphite coated pottery technology. Journal of Archaeological Science 52, 129-152.

Kulbicki, G. 1958. High-temperature phases in montmorillonites. In: A. Swineford (ed.), Clays and Clay Minerals. Washington, DC: National Academy of Sciences/National Research Council, 144-158.

Leshtakov, P. 2005. The sources and distribution of graphite as a means of decoration in the Bulgarian Chalcolithic. In: G. Dumitroaia, J. Chapman, O. Weller, C. Preoteasa, R. Munteanu, D. Nicola and D. Monah (eds), 120 Years of Research. Time to Sum Up. Piatra-Neamţ: Constantin Matasă, 293-297.

Letsch, J. and Noll, W. 1978. Material und Herstellung antiker C-Schwarz-Keramik, Teil I / Teil II. Berichte der Deutschen Keramischen Gesellschaft 55, 163-168 and 259-261.

Letsch, J. and Noll, W. 1983. Phasenbildung in einigen keramischen Teilsystemen bei 600$1000{ }^{\circ} \mathrm{C}$ in Abhängigkeit von der Sauerstofffugazität. Ceramic Forum International 7, 259267.

Lienhard, J. H. 2006. How Invention Begins. Oxford: Oxford University Press. 
Maggetti, M. 1982. Phase analysis and its significance for technology and origin. In: J. S. Olin and A. D. Franklin (ed.), Archaeological Ceramics. Washington, DC: Smithsonian Institute Press, 121-133.

Maniatis, Y. and Tite, M. S. 1975. A scanning electron microscope examination of the bloating of fired clays. Transactions and Journal of the British Ceramic Society 74(8), 229-232.

Maniatis, Y. and Tite, M. S. 1981. Technological examination of Neolithic Bronze-Age pottery from Central and Southeast Europe and from the Near-East. Journal of Archaeological Science $8,59-76$.

Marić, M., Mirković-Marić, N., Molloy, B., Jovanović, D., Mertl, P., Milašinović, L. and Pendić, J. 2016. New results of the archaeological excavations on the site Gradište near Iđoš: Season 2014. Glasnik Srpskog Arheološkog Društva 32, 125-144.

Maritan, L. 2004. Archaeometric study of Etruscan-Padan type pottery from Veneto region: Petrographic, mineralogical and geochemical-physical characterisation. European Journal of Mineralogy 16, 297-307.

Maritan, L., Mazzoli, C. and Freestone, I. 2007. Modelling changes in mollusc shell internal microstructure during firing: Implications for temperature estimation in shell-bearing pottery. Archaeometry 49, 529-541.

Martinon, S. 2017. Graphite-treated pottery in the Northeastern Mediterranean from the Chalcolithic to the Bronze Age. Near Eastern Archaeology 80, 3-13.

McDonnell, J. G. 2001. Pyrotechnology. In: D. R. Brothwell and M. Pollard (eds), Handbook of Archaeological Science. London: Wiley, 493-506.

Mentesana, R., Kilikoglou, V., Todaro, S. and Day, P. M. 2017. Reconstructing change in firing technology during the final Neolithic-Early Bronze Age transition in Phaistos, Crete. Just the tip of the iceberg? Archaeological and Anthropological Sciences 9, 871-894.

Milojčić, V. 1949. Chronologie der jüngeren Steinzeit Mittel- und Südosteuropas. Berlin: Mann.

Nodari, L., Marcuz, E., Maritan, L., Mazzoli, C. and Russo, U. 2007. Hematite nucleation and growth in the firing of carbonate-rich clay for pottery production. Journal of the European Ceramic Society 27, 4665-4673.

Noll, W. 1991. Alte Keramiken und ihre Pigmente. Stuttgart, Schweizerbart.

Perić, S., 2006. The Gradac period in the Neolithic settlements in the Morava valley. In: N. Tasić and C. Grozdanov (eds), Homage to Milutin Garašanin. Belgrade: Serbian Academy of Sciences and Arts, 235-250.

Perišić, N., Marić-Stojanović, M., Andrić, V., Mioč, U. B. and Damjanović, L. 2016. Physicochemical characterisation of pottery from Vinča culture, Serbia regarding the firing temperature and decoration technique. Journal of the Serbian Chemical Society 81(12), 14151426. 
Pollard, A. M., Thomas, R. G., Ware, D. P. and Williams, P. A. 1991. Experimental smelting of secondary copper minerals: Implications for Early Bronze Age metallurgy in Britain. In: E. Pernicka and G. A. Wagner (eds), Archaeometry '90: International Symposium in Archaeometry, Basel: Birkhäuser, 127-136.

Quinn, P. S. 2013. Ceramic Petrography. The Interpretation of Archaeological Pottery and Related Artefacts in Thin Section. Oxford: Archaeopress.

Quinn, P. S. and Benzonelli, A. 2018. XRD and materials analysis. In: S. Lopez Varela (ed.), The Encyclopedia of Archaeological Sciences. New York: Wiley, 1796-1800.

Radivojević, M. 2012. On the Origins of Metallurgy in Europe: Metal Production in the Vinča Culture. Unpublished Ph.D. thesis, University College London.

Radivojević, M. 2013. Archaeometallurgy of the Vinča culture: A case study of the site of Belovode in eastern Serbia. Journal of Historical Metallurgy Society 47, 13-32.

Radivojević, M. 2015. Inventing metallurgy in western Eurasia: A look through the microscope lens. Cambridge Archaeological Journal 25, 321-338.

Radivojević, M. and Grujić, J. 2018. Community structure of copper supply networks in the prehistoric Balkans: An independent evaluation of the archaeological record from the $7^{\text {th }}$ to the 4th millennium BC. Journal of Complex Networks 6, 106-124.

Radivojević, M. and Kuzmanović-Cvetković, J. 2014. Copper minerals and archaeometallurgical materials from the Vinča culture sites of Belovode and Pločnik: Overview of the evidence and new data. Starinar 64, 8-30.

Radivojević, M. and Rehren, Th. 2016. Paint it black: The rise of metallurgy in the Balkans. Journal of Archaeological Method and Theory 22, 200-237.

Radivojević, M., Rehren, Th., Pernicka, E., Šljivar, D., Brauns, M. and Borić, D. 2010. On the origins of extractive metallurgy: New evidence from Europe. Journal of Archaeological Science 37, 2775-2787.

Radivojević, M., Rehren, Th., Kuzmanović-Cvetković, J., Jovanović, M. and Northover, J. P. 2013. Tainted ores and the rise of tin bronze metallurgy, c. 6500 years ago. Antiquity 87, 10301045 .

Radivojević, M., Rehren, Th., Farid, S., Pernicka, E. and Camurcuoglu, D. 2017. Repealing the Çatalhöyük extractive metallurgy: The green, the fire and the 'slag'. Journal of Archaeological Science 86, 101-122.

Radivojević, M., Roberts, B. W., Kuzmanović-Cvetković, M., Marić M. and Rehren Th. (eds.) forthcoming. The Rise of Metallurgy in Eurasia: The Archaeology of Early Metallurgy and Society in the Central Balkans. London: UCL Press.

Rehren, Th. 1997. Die Rolle des Kohlenstoffs in der prähistorischen Metallurgie. Stahl und Eisen 117, 87-92. 
Renfrew, C. 1969. The autonomy of the south-east European Copper Age. Proceedings of the Prehistoric Society 35, 12-47.

Renfrew, C. 1970. The place of Vinča culture in European prehistory. Zbornik Radova Narodnog Muzeja 6, 45-57.

Renfrew, C. 1973. Sitagroi and the independent invention of metallurgy in Europe. In: M. Garašanin, A. Benac and N. Tasiš (eds), Actes du VIIIe congrès international des sciences préhistoriques et protohistoriques. Belgrade: Union Internationale des Sciences Préhistoriques et Protohistoriques, 473-481.

Renfrew, C. 1978. The anatomy of innovation. In: D. Green, C. Haselgrove and M. Spriggs (eds), Social Organization and Settlement. Oxford: British Archaeological Reports, 89-117.

Rice, P. M. 2015. Pottery Analysis: A Source Book. Chicago, IL: University of Chicago Press.

Roberts, B. W. and Radivojević, M. 2015. Invention as a process: Pyrotechnologies in early societies. Cambridge Archaeological Journal 25, 299-306.

Roberts, B. W., Thornton C. P. and Pigott, V. C. 2009. Development of metallurgy in Eurasia. Antiquity 83, 1012-1022.

Schier, W. 1996. The relative and absolute chronology of Vinča: New evidence from the type site. In: F. Draşovean (ed.), The Vinča Culture, its Role and Cultural Connections. Timişoara: National Museum, 141-162.

Schier, W. 2000. Measuring change: The Neolithic pottery sequence of Vinča-Belo Brdo. Documenta Praehistorica 27, 187-197.

Spataro, M. 2014. Continuity and change in pottery manufacture between early and middle Neolithic of Romania. Archaeological and Anthropological Sciences 6, 175-197.

Spataro, M. 2017. Innovation and regionalism in the Middle/Late Neolithic of south and southeastern Europe (ca. 5,500-4,500 cal. BC): A ceramic perspective. In: L. Burnez-Lanotte (ed.), Matières à Penser. Raw Materials Acquisition and Processing in Early Neolithic Pottery Productions. Proceedings of the Workshop of Namur (Belgium), 29-30 May 2015. Paris: Société préhistorique française, 61-72.

Spataro, M. 2018. Origins of specialization: The ceramic chaîne opératoire and technological take-off at Vinča-Belo Brdo, Serbia. Oxford Journal of Archaeology 37, 247-265.

Spataro, M., 2019. Production and function of Neolithic black-painted pottery from Schela Cladovei (Iron Gates, Romania). Archaeological and Anthropological Sciences 11, 6287-6304.

Svoboda, V., Vuković, J., Knežević, S., Izvonar, D. and Kićević, D. 2004/2005. Experimental archaeology: Traditional production of ceramics, presentation of phase I. Diana 10, 123-131.

Tasić, N., Marić, M., Penezić, K., Filipović, D., Borojević, K., Russell, N., Reimer, P., Barclay, A., Bayliss, A., Borić, D., Gaydarska, B. and Whittle, A. 2015. The end of the affair: Formal 
chronological modelling for the top of the Neolithic Tell of Vinča-Belo Brdo. Antiquity 89 (347), 1064-1082.

Tite, M. S. and Maniatis, Y. 1975a. Scanning electron microscopy of fired calcareous clays. Transactions and Journal of the British Ceramic Society 74, 19-22.

Tite, M. S. and Maniatis, Y. 1975b. Examination of ancient pottery using the scanning electron microscope. Nature 257, 122-123.

Todorova, H. 1981. Die kupferzeitlichen Äxte und Beile in Bulgarien. München: C. H. Beck.

Todorova, H. 1986. Kamenno-Mednata Epokha v Bulgariya. Peto Khilyadoletie predi Novata Era (Chalcolithic in Bulgaria, 5th millennium BC). Sofia: Nauka i Izkustvo.

Vajsov, I. 2007. Promachon-Topolnica. A typology of painted decorations and its use as a chronological marker. In: H. Todorova, M. Stefanovich and G. Ivanov (eds), The Struma/Strymon River Valley in Prehistory. Proceedings of the International Symposium "Strymon Praehistoricus". Düsseldorf: Gerda Henkel Stiftung, 79-120.

Vucović, J. 2011. Late Neolithic pottery standardization. Application of statistical analysis. Glasnik Srpskog archeološkog društva 27, 81-101.

Vuković, J. 2018. Late Neolithic Vinča Pottery Firing Procedure. Opuscula Archaeologica 39(40), 25-35.

Weber, R. J., Dixon, S. and Llorente, A. M. 1993. Studying invention: The hand tools as model system. Science, Technology and Human Values 18, 480-505.

Wertime, Th. A. 1964. Man's first encounters with metallurgy. Science 146(3649), 1257-1267.

Whitbread, I. K. 1995. Greek Transport Amphorae: A Petrological and Archaeological Study. Athens: British School at Athens.

Whittle, A., Bayliss, A., Barclay, A., Gaydarska, B., Bánffy, E., Borić, D., Draşovean, F., Jakucs, J., Marić, M., Orton, D., Pantović, I., Schier, W., Tasić, N. and Vander Linden, M. 2016. A Vinča potscape: Formal chronological models for the use and development of Vinča ceramics in south-east Europe. Documenta Praehistorica 43, 1-60.

Wolf, S. 2002. Estimation of the production parameters of very large Medieval bricks from St. Urban, Switzerland. Archaeometry 44, 37-45.

Wu, X., Zhang, C., Goldberg, P., Cohen, D., Yan, P.Y., Arpin, T. and Bar-Yosef, O. 2012. Early Pottery at 20,000 Years Ago in Xianrendong Cave, China. Science 336(6089), 16961700 .

Yiouni, P. 1995. Technological analysis of the Neolithic pottery from Makri. Bulletin de Correspondance Hellénique 119(2), 607-620.

Yiouni, P. 2000. Painted pottery from East Macedonia in North Greece: Technological analysis of decorative techniques. Documenta Praehistorica 27, 198-214. 
Yiouni, P. 2001. Surface treatment of Neolithic vessels from Macedonia and Thrace. The Annual of the British School at Athens 96, 1-25. 